UNIVERSIDADE DE SÃO PAULO

FACULDADE DE MEDICINA DE RIBEIRÃO PRETO

\title{
Efeitos neuroprotetores do Edaravone na hidrocefalia experimental induzida em ratos Wistar.
}

\author{
Aluna: Camila Araújo Bernardino Garcia
}

Dissertação apresentada à Faculdade de Medicina de Ribeirão Preto da Universidade de São Paulo, como parte das exigências para obtenção do título de Mestre em Ciências Médicas. Área de concentração: Morfologia e Medicina Experimental. Orientador: Prof. Dr. Hélio Rubens Machado. Departamento de Cirurgia e Anatomia.

Ribeirão Preto 
AUTORIZO A REPRODUÇÃO E DIVULGAÇÃO PARCIAL OU TOTAL DESTE TRABALHO, POR QUALQUER MEIO CONVENCIONAL OU ELETRÔNICO, PARA FINS DE ESTUDO E PESQUISA, DESDE QUE CITADA A FONTE.

FICHA CATALOGRÁFICA

\section{Garcia, Camila Araújo Bernardino}

Efeitos neuroprotetores do Edaravone na hidrocefalia experimental induzida em ratos Wistar. Ribeirão Preto, 2015.

$85 \mathrm{p} ; \mathrm{Il}, ;$ p.: $30 \mathrm{~cm}$

Dissertação de Mestrado, apresentada à Faculdade de Medicina de Ribeirão Preto/USP. Área de concentração: Morfologia e Medicina Experimental.

Orientador: Machado, Hélio Rubens

1. Hidrocefalia experimental. 2. Neuroproteção. 3. Edaravone. 
GARCIA, C.A.B. Efeitos neuroprotetores do Edaravone na hidrocefalia experimental induzida em ratos Wistar. 2015. Dissertação apresentada à Faculdade de Medicina de Ribeirão Preto da Universidade de São Paulo, para a obtenção do título de Mestre em Ciências Médicas - opção: Morfologia e Medicina Experimental.

Aprovado em:

\section{BANCA EXAMINADORA}

Prof. Dr.

Julgamento:
Instituição:

Assinatura:
Prof. Dr.

Julgamento:
Instituição: Assinatura:
Prof. Dr.

Julgamento:
Instituição: Assinatura: 


\section{DEDICATÓRIA}

À minha querida mãe Márcia Cassis pelo amor e incentivo incansável. 


\section{AGRADECIMENTOS}

\section{Luiza da Silva Lopes}

Que sem reservas me ensinou e me instruiu ao longo desta etapa, sempre disposta à indicação de leituras e execução da parte prática. Agradeço a forma generosa como me orientou neste trabalho e pelo apoio durante minha fase de amadurecimento profissional e pessoal.

\section{Hélio Rubens Machado}

Pelo exemplo de caráter e profissionalismo, sua sensibilidade de dizer as palavras certas nos momentos mais apropriados me ajudou a dar rumo à pesquisa e despertar o olhar científico. Sou imensamente grata por confiar em mim e sempre motivar meu desenvolvimento intelectual.

\section{Aos meus amigos e companheiros de laboratório}

Á todos os amigos do laboratório, pelos dias de trabalho divididos com alegria e bom humor. Muito obrigada a cada um pela dedicação e compreensão nos momentos estressantes.

\section{Casa de hóspedes da USP - campus Ribeirão Preto}

Aos funcionários que me acolheram com muito carinho e atenção por todos os dias letivos!

\section{Funcionários do Departamento de Cirurgia e Anatomia}

Pelo apoio, cuidado e disposição em ajudar sempre que necessário. Agradeço tanto carinho.

FAEPA - Fundação de Apoio ao Ensino, Pesquisa e Assistência do Hospital das Clínicas da Faculdade de Medicina de Ribeirão Preto da Universidade de São Paulo

Ao auxilio financeiro em congressos e eventos que participei.

\section{FAPESP - Fundação de Amparo a Pesquisa do Estado de São Paulo}

Pela concessão da bolsa e pelo apoio financeiro para realização desta pesquisa.

A todos compartilho a alegria de ter realizado este trabalho. 


\section{Á minha família}

Aos meus pais Mauro Bernardino e Márcia Cassis, um exemplo de sucesso e amor incondicional. Muito obrigada pelo apoio nas horas difíceis, pelo incentivo e principalmente por me motivarem a ser uma pessoa honesta e esforçada. Á minha irmã Marcela Araújo, confidente e companheira, que sempre esteve ao meu lado sofrendo comigo os nervosismos das préapresentações e seleções para matricular no programa de pós-graduação. Ao meu esposo Marlon Garcia e grande amor da minha vida, que com muito carinho e cumplicidade sempre me incentivou, acreditou no meu crescimento profissional e compreendeu minha ausência em casa por morar em outra cidade me dedicando aos estudos, com um companheirismo incansável! Amo todos vocês! 


\section{Resumo}

GARCIA, C.A.B. "Efeitos neuroprotetores do Edaravone na hidrocefalia experimental induzida em ratos Wistar". 2015. 85f. Faculdade de Medicina de Ribeirão Preto da Universidade de São Paulo, Ribeirão Preto, 2015.

Introdução: Hidrocefalia é uma síndrome caracterizada pelo acúmulo de líquido cérebroespinal no interior das cavidades ventriculares. Considerando a sua fisiopatologia de caráter multifatorial um dos fatores envolvidos é o estresse oxidativo desencadeado pela peroxidação lipídica e formação de radicais livres. O Edaravone é um novo fármaco antioxidante com efeitos neuroprotetores, que ainda não foi testado em pacientes com hidrocefalia. Objetivo: Avaliar a resposta neuroprotetora do Edaravone na hidrocefalia experimental em ratos jovens. Metodologia: A hidrocefalia foi induzida em ratos filhotes, injetando uma porção de caulim na cisterna magna. Os animais foram divididos em três grupos: controle (C) $(n=10)$; hidrocefalia não tratada (HNT) $(\mathrm{n}=20)$; hidrocefalia tratado com $20 \mathrm{mg} / \mathrm{kg}$ Edaravone (HTE) $(\mathrm{n}=20)$. O grupo tratado com a droga recebeu todos os dias, a partir do primeiro dia após a indução, uma injeção intraperitoneal com o Edaravone. Os animais foram pesados diariamente, avaliados por testes comportamentais e exame de ressonância magnética, análise histopatológica, imunoistoquímica e bioquímica. Todos os animais foram sacrificados, 14 dias após a indução de hidrocefalia. Resultados: Do terceiro ao oitavo dia após a indução de hidrocefalia, os animais ganharam menos peso do que os controles. No entanto, a partir do nono dia pós-indução, o ganho de peso foi similar nos três grupos experimentais. No teste de campo aberto e no labirinto aquático, o desempenho dos animais do grupo HTE foi melhor, quando comparado com os animais do grupo HNT. Na imunoistoquímica para GFAP, os animais do grupo HNT demonstravam astrócitos intensamente marcados com extensões grossas, enquanto que os animais do grupo de HTE tinham astrócitos mais delicados e com extensões finas. $\mathrm{Na}$ análise por caspase-3 os animais tratados com Edaravone mostraram um número menor de células em processos de apoptose. Conclusões: O uso do Edaravone evidenciou uma tendência a diminuir células em processo de apoptose, melhorou a resposta comportamental, e atividade dos astrócitos ligeiramente reduzida evidenciado por GFAP imunomarcação no corpo caloso de ratos jovens com hidrocefalia.

Palavras-chave: hidrocefalia experimental, neuroproteção, Edaravone. 


\begin{abstract}
GARCIA, C.A.B. "Neuroprotective effects of edaravone in experimentally induced hydrocephalus in Wistar rats." 2015. 85f. School of Medicine of Ribeirão Preto, University of São Paulo, Ribeirão Preto - SP, Brazil, 2015.
\end{abstract}

Background: Hydrocephalus is a syndrome resulting from the current unbalance between the formation and absorption of cerebrospinal fluid (CSF), and consequent accumulation within the cerebral ventricles. Clinically, hydrocephalic children can present several neurological disorders, not always reversed with treatment, even after the development of more and more sophisticated shunt systems (1). Although lesions of hydrocephalus be multifactorial, it is known that oxidative stress is one of the mechanisms involved. The Edaravone is a new antioxidant drug with neuroprotective effects but has not been tested in hydrocephalus (2). Objectives: To evaluate the neuroprotective response of Edaravone on experimental hydrocephalus in young rats. Methodology: Hydrocephalus was induced in pup rats by injecting kaolin into the cisterna magna. The animals were divided into three groups with 10 rats each one: control (C); untreated hydrocephalus (HNT); hydrocephalus treated with $20 \mathrm{mg} / \mathrm{kg}$ Edaravone (HTE). The treated group receive the drug every day from the first day after induction. The animals were weighed daily, assessed by behavioral tests and magnetic resonance examination. All animals were sacrificed 14 days after hydrocephalus induction and the brains processed for histological, immunohistochemical and biochemical analysis. In the analysis of caspase- 3 treated animals showed Edaravone a smaller number of cells in the process of apoptosis. Results: From the third to the eighth day after the hydrocephalus induction, the animals gained less weight than controls. However, from the ninth day of induction, weight gain was similar in the 3 experimental groups. In the open field test the performance of hydrocephalic rats receiving Edaravone was better than those who did not receive the drug. In immunohistochemistry for GFAP in the corpus callosum, the control rats did not exhibit reactive astrocytes. On the other hand, the animals of HNT group showed intensely labeled astrocytes with thick extensions, while the animals in the HTE group the astrocytes were more delicate and with thin extensions. Conclusion: The use of Edaravone showed a tendency to decrease in cell apoptosis improved the behavioral response and slightly reduced astrocyte activity evidenced by GFAP immunostaining in the corpus callosum of young rats with hydrocephalus.

Keywords: experimental hydrocephalus, neuroprotection, Edaravone. 


\section{Lista de figuras}

Figura 1 - Indução da hidrocefalia com posicionamento do rato por um auxiliar e punção percutânea da cisterna magna e injeção do caulim pelo pesquisador.

Figura 2 - Posicionamento do animal no gantry do aparelho de ressonância magnética de $3 \mathrm{~T}$, em bobina própria para pequenos roedores, para aquisição das imagens no $13^{\circ}$ dia de vida. 32

Figura 3 -Detalhes sobre os parâmetros de sequência. 33

Figura 4 - A. Imagem obtida por RM, sequência em T2, em reconstrução coronal média, com delimitação das áreas de interesse (ROI) (Azul= ROI dorsal do ventrículo lateral / Violeta=ROI ventral do ventrículo lateral) que foram usadas para quantificação da mielina, e delimitação das áreas do encéfalo e dos ventrículos laterais para cálculo da razão ventricular (Área vermelha = ventrículo lateral $/$ Área verde= encéfalo total)........34

Figura 5 - Gráfico representativo das médias dos pesos diários, dos ratos dos diferentes grupos experimentais. Grupos: $\mathrm{C}$ : controle, $\mathrm{H}$ : hidrocefálico sem tratamento e HTE: hidrocefálico tratado com edaravone A: P6, B:P7, C:P8, D: evolução das médias de peso diários dos animais de diferentes grupos experimentais.Os animais controles (C) apresentavam um ganho de peso semelhante aos animais do grupo HNT de P6 a P8 $(\mathrm{p}<0,05)$.

Figura 6: Gráficos representativos do desempenho no teste de campo aberto (open field). Grupos: C: controle, H: hidrocefálico sem tratamento e HTE: hidrocefálico tratado com edaravone A: P8, B: P10, C:P12, D: P14. Os animais do grupo HTE, mostravam maior capacidade funcional, quando comparados com os outros grupos $(\mathrm{p}<0,05)$.

Figura 7: Gráficos representativos do desempenho no teste de memória (Labirinto Aquático de Morris), Grupos: C: controle, HNT: hidrocefálico sem tratamento e HTE: hidrocefálico tratado com edaravone mostrando que os animais do grupo HTE apresentaram melhor desempenho (chegavam à plataforma em tempo mais curto), quando comparados com os animais hidrocefálicos sem tratamento (HNT).

Figura 8 - Gráfico representativo da comparação das medidas de razão ventricular (RV), nos grupos estudados. Grupos: C: controle, $\mathrm{H}$ : hidrocefálico sem tratamento e HTE: hidrocefálico tratado com edaravone. Os animais do grupo HNT/HTE, apresentaram RV 
semelhante entre si. Na comparação dos grupos hidrocefálicos com o grupo $\mathrm{C}$, as médias da RV de ambos os grupos hidrocefálicos eram maiores que a média do grupo controle $(\mathrm{p}<0,01)$

Figura 9 - Gráfico representativo da transferência de magnetização, A: região ventral ao ventrículo lateral, B: região dorsal ao ventrículo lateral, e C: encéfalo total. Grupos: C: controle, H: hidrocefálico sem tratamento e HTE: hidrocefálico tratado com edaravone. Não houve diferença nos valores obtidos no encéfalo total e nas áreas dorsais e ventrais ao ventrículo lateral, entre os grupos estudados. $\mathrm{Na}$ análise do encéfalo total os animais controles apresentavam uma média de transferência de magnetização maior quando comparados com os animais dos grupos hidrocefálicos.

Figura 10 - Fotomicrografias do encéfalo de rato hidrocefálico (A) corpo caloso, (B) matriz germinativa, (C) córtex cerebral, (D) cápsula externa (entre as setas), fotomiografias do encéfalo de rato controle $(\mathrm{E})$ matriz germinativa $(\mathrm{F})$ cápsula externa (entre as setas), $(\mathrm{G})$ córtex cerebral e $(\mathrm{H})$ corpo caloso (quadrado) (VL) ventrículo lateral. Pode se observar nos encéfalos dos ratos hidrocefálicos, edema leve (círculo), região da matriz germinativa (estrela) com ângulo do ventrículo dilatado. Nos encéfalos dos animais controles a laminação manteve preservada. Coloração- hematoxilina e

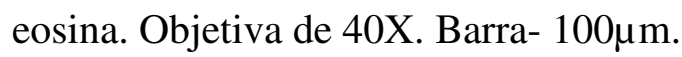

Figura 11 -Comparação da tonalidade em azul no corpo caloso, tabulada através de um score de 0 a 2. Grupos: C: controle, HNT: hidrocefálico sem tratamento e HTE: hidrocefálico tratado com edaravone Houve diferença estatística entre os grupos hidrocefálicos comparados com o grupo controle, mostrando que os animais do grupo controle apresentavam uma progressiva mielinização em relação aos animais hidrocefálicos $(* \mathrm{p}<0,05)$.

Figura 12 - Fotomicrografias do corpo caloso de ratos (21 dias de vida) - (A) Controle (B) Hidrocefálico não tratado (C) Hidrocefálico tratado com Edaravone, mostrando maior espessura do corpo caloso nos animais controles em relação aos grupos hidrocefálicos. Coloração: solocromo-cianina. Objetiva de 10X. Exposição de luz: 90.0 ms. Barra - 100 $\mu \mathrm{m}(*)$ corpo caloso.

Figura 13 - Comparação das medidas de espessura de corpo caloso, demonstrando diferença entre o grupo controle e os grupos hidrocefálicos $(* \mathrm{p}<0,01)$. Grupos: C: controle, HNT: hidrocefálico sem tratamento e HTE: hidrocefálico tratado com 
edaravone Não houve diferença entre o grupo hidrocefálico não tratado e o tratado com Edaravone.

Figura 14 - Correlação linear de Spearman $(\mathrm{p}<0.0001)$. Mostrando que há uma correlação significante entre a espessura do corpo caloso e razão ventricular.

Figura 15 - Fotomicrografias da matriz germinativa com imunomarcação para o GFAP de ratos (21 dias de vida) (A) Controle (B) Hidrocefálico não tratado (C) Hidrocefálico tratado com Edaravone. Observa-se que o grupo hidrocefálico não tratado apresenta astrócitos intensamente marcados, quando comparados com os outros grupos experimentais. Fotomicrografias do corpo caloso com imunomarcação para o GFAP de ratos (21 dias de vida), (D) Controle. (E) Hidrocefálico não tratado. (F) Hidrocefálico tratado com Edaravone. Observa-se que o grupo hidrocefálico não tratado apresenta astrócitos intensamente marcados, quando comparados com os outros grupos experimentais. Objetiva de 40X (imersão). Barra - $20 \mu \mathrm{m}$.

Figura 16 - Gráfico representativo da densidade de astrócitos imunomarcados pelo GFAP. Grupos: C: controle, H: hidrocefálico sem tratamento e HTE: hidrocefálico tratado com edaravone A. na região do corpo caloso e B. matriz germinativa nos diferentes grupos experimentais. Demonstração dos animais pertencentes ao grupo não tratado com uma maior reação astrocitária quando comparado com grupo controle $* \mathrm{p}<0,05$.

Figura 17 - Gráfico representativo da densidade dos astrócitos imunomarcados por GFAP categorizado por um score. Grupos: C: controle, HNT: hidrocefálico sem tratamento e HTE: hidrocefálico tratado com edaravone Os animais do grupo HNT, mostraram-se com uma marcação mais intensa e proliferativa no corpo caloso e na matriz germinativa, quando comparados com os outros grupos experimentais. $\mathrm{Na}$ comparação entre os grupos HTE/HNT com o grupo $\mathrm{C}$, houve diferença estatística significativa, mostrando que os animais do grupo controle obtiveram uma média menor em relação aos grupos hidrocefálicos.

Figura 18 -Gráfico representativo da densidade de células em divisão mitótica imunomarcadas pelo anticorpo Ki-67. Grupos: C: controle, H: hidrocefálico sem tratamento e HTE: hidrocefálico tratado com edaravone na região da matriz germinativa nos diferentes grupos experimentais. $\mathrm{Na}$ comparação dos grupos hidrocefálicos HNT/HTE com o grupo C, mostrou-se que os animais do grupo controles exibiram densidade celular significativamente maior que os demais grupos $(\mathrm{p}<0,01)$. 
Figura 19 -Fotomicrografias da matriz germinativa com imunomarcação para o Ki-67 de ratos (21 dias de vida) (A) Controle (B) Hidrocefálico não tratado (C) Hidrocefálico tratado com Edaravone.. Observa-se que o grupo C apresenta maior proliferação celular, quando comparados com os outros grupos experimentais, proliferação celular (estrela), ventrículo lateral (VL). Objetiva de 40X (imersão). Barra - $20 \mu \mathrm{m}$.

Figura 20 - Gráfico representativo referente à imunomarcação pelo anticorpo caspase-3. Grupos: C: controle, H: hidrocefálico sem tratamento e HTE: hidrocefálico tratado com edaravone no (A) córtex cerebral dorsal e (B) corpo caloso, nos diferentes grupos experimentais $(* \mathrm{p}<0.01)$, demonstrando que na região do córtex dorsal, os animais do grupo HTE apresentaram uma quantidade menor de células em apoptose em relação ao grupo HNT

Figura 21 - Gráfico representativo referente à reação microglial. Grupos: C: controle, HNT: hidrocefálico sem tratamento e HTE: hidrocefálico tratado com edaravone (A) corpo caloso e (B) córtex dorsal nos diferentes grupos experimentais. (A) Mostra que os animais do grupo HNT apresentaram uma reação microglial maior do que os animais do grupo $\mathrm{C}$, com diferença significativa $(\mathrm{p}=<0.01)$ na comparação entre os grupos hidrocefálicos não houve diferenças estatísticas.

Figura 22 - Gráfico representativo referente aos valores de glutationa presentes no tecido. Grupos: C: controle, H: hidrocefálico sem tratamento e HTE: hidrocefálico tratado com edaravone. Os animais tratados com Edaravone mostraram um nível menor de glutationa, quando comparados com os outros grupos, porém sem diferenças estatísticas. 59

Figura 23 - Gráfico representativo referente aos valores de antioxidantes totais presentes no plasma. Grupos: C: controle, H: hidrocefálico sem tratamento e HTE: hidrocefálico tratado com edaravone Os animais do grupo $\mathrm{C}$ mostraram uma média maior referente ao nível de antioxidantes, quando comparados com os outros grupos com diferenças estáticas significativas $(* \mathrm{p}<0,05)$.

Figura 24 - Gráfico representativo referente aos valores de malondeido, presentes no tecido. Grupos: C: controle, H: hidrocefálico sem tratamento e HTE: hidrocefálico tratado com edaravone Os animais tratados com Edaravone mostraram um nível maior, quando comparados com os outros grupos, porém sem diferenças estatísticas. 61 


\section{Sumário}

1.INTRODUÇÃ

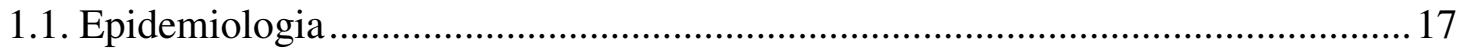

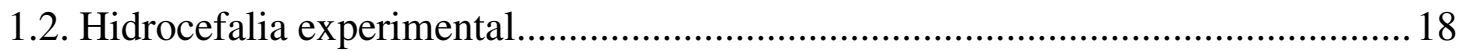

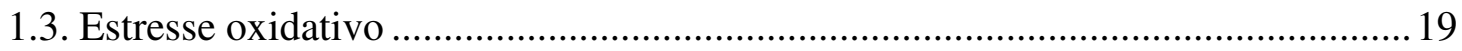

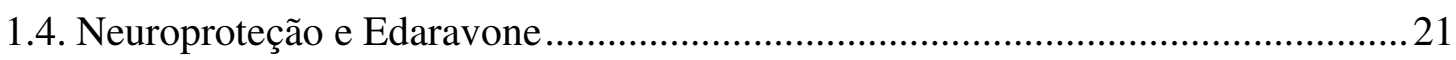

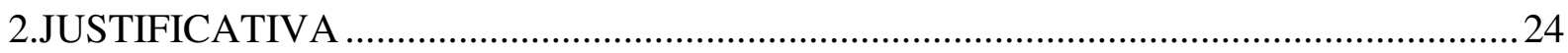

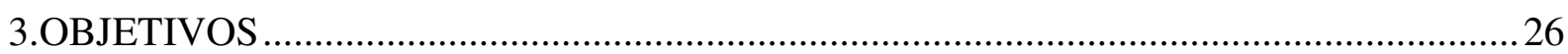

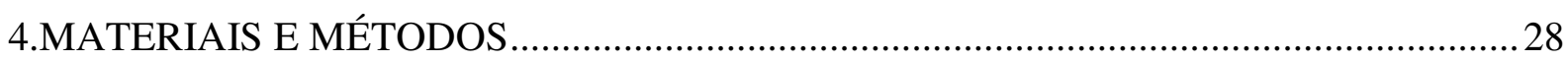

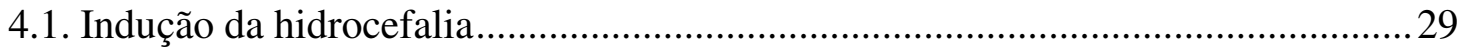

4.2. Formaçãa dos grupos experimentais...................................................................... 30

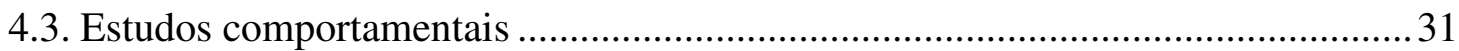

4.4. Estudos por ressonância magnética .................................................................. 32

4.5. Coleta das amostras: perfusão cerebral e dissecção de estruturas .......................... 34

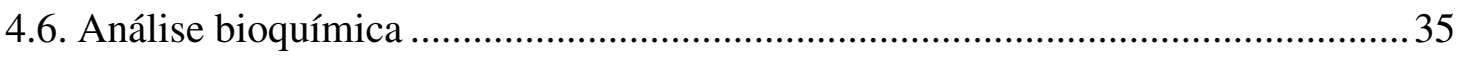

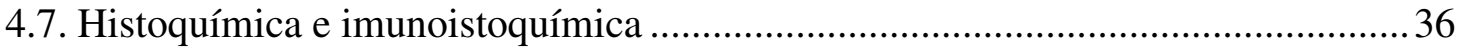

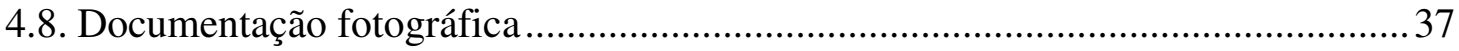

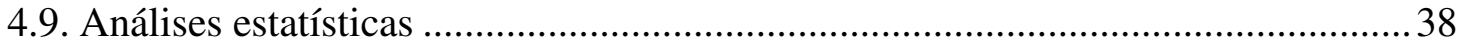

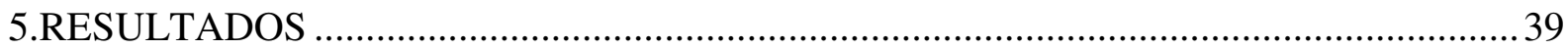

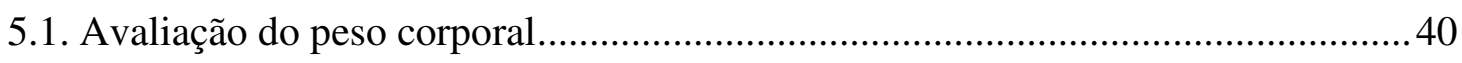

5.2. Avaliação comportamental geral ........................................................................ 41

5.3. Avaliação comportamental com testes específicos.............................................. 41

5.3.1. Teste de campo aberto (open field) ................................................. 41

5.3.2. Labirinto aquático de morris (water maze) …...................................... 42

5.4. Avaliação por ressonância magnética..................................................................... 43

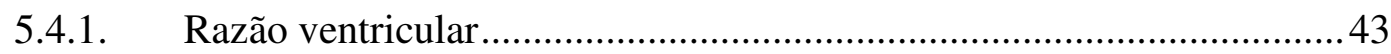

5.4.2. Transferência de magnetização ......................................................... 44

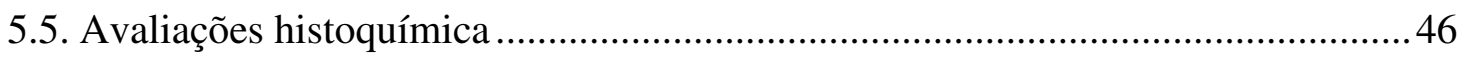

5.5.1. Coloração com hematoxilina e eosina............................................... 46

5.5.2. Coloração com solocromo-cianina .................................................... 48 


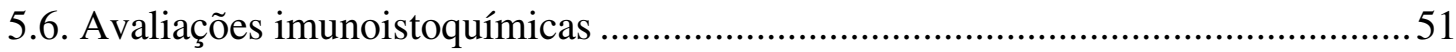

5.6.1. Estudo imunoistoquímico do GFAP......................................................

5.6.2. Estudo imunoistoquímico do Ki-67 .....................................................54

5.6.3. Estudo imunoistoquímico por caspase-3 …………………………….....57

5.6.4. Estudo da reação microglial por lectina ...................................................57

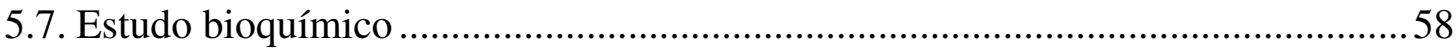

5.7.1. Avaliação da atividade da glutationa peroxidase ……………………....58

5.7.2. Avaliação dos antioxidantes totais presentes no plasma .........................59

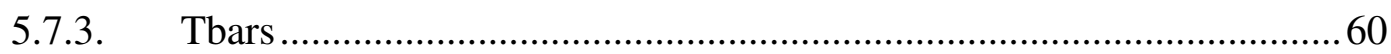

6.DISCUSSÃO

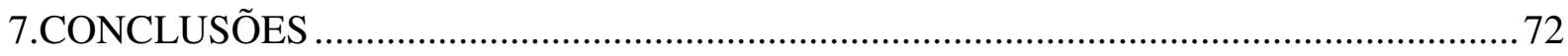

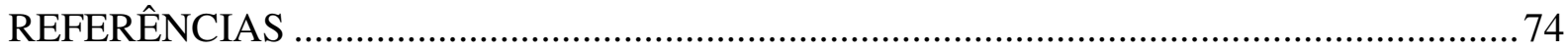

ANEXOS82 
1. INTRODUÇÃO 
A hidrocefalia é uma doença de complexa fisiopatologia, que não só afeta a dinâmica do líquido cefalorraquidiano (LCR), mas também atinge outras estruturas do sistema nervoso central. $\mathrm{O}$ desequilíbrio entre a produção e absorção de LCR resulta em um aumento do volume ventricular e levando a distorções no parênquima cerebral, comprimindo os hemisférios contra a superfície interna do crânio (DEL BIGIO; BRUNI; FEWER, 1985).

Várias classificações tentam definir a hidrocefalia com critérios diversos, não sendo nenhuma classificação completa e satisfatória. Quanto aos processos patológicos, podem ser de desenvolvimento agudo ou crônico. Além disso, a hidrocefalia pode ainda ser classificada de acordo com o ponto de bloqueio da circulação liquórica, em não comunicante, quando o bloqueio encontra-se dentro do sistema ventricular, e comunicante, quando o bloqueio é fora do sistema ventricular, afetando as cisternas da base do encéfalo, ou outros pontos do espaço subaracnóideo, ou ainda as vilosidades aracnóideas. A hidrocefalia pode ser causada por obstrução das vias do líquido cérebro-espinal, ou por superprodução do mesmo. Estas duas causas básicas podem ser desencadeadas por neoplasias, malformações congênitas ou processos inflamatórios (MILHORAT, 1979).

A produção liquórica normal em um homem adulto é de cerca de $500 \mathrm{ml}$ por dia. Como o espaço liquórico comporta entre 130 e $140 \mathrm{ml}$, existe troca total do líquido cérebro-espinal, por 3 ou 4 vezes ao dia (MCLONE, 1994). Na hidrocefalia, com a dinâmica liquórica alterada e o acúmulo de líquido cérebro-espinal no sistema ventricular dilatado, ocorre uma estagnação e deficiência na eliminação de metabólitos (CASTRO-GAGO et al., 1989). Com o acúmulo do líquido cérebro-espinal nas cavidades ventriculares, a pressão intracraniana se eleva principalmente nos estágios agudos da hidrocefalia obstrutiva. Todavia, o incremento na pressão intracraniana não é o único fator implicado na gênese da dilatação ventricular. Isto pode ser constatado na hidrocefalia de pressão normal, na qual a pressão intracraniana, aparentemente compensada, retorna a valores normais, durante $o$ desenvolvimento do processo, não impedindo que a dilatação ventricular progrida. Provavelmente, o que na verdade leva à dilatação dos ventrículos cerebrais é o gradiente de pressão entre estes e o parênquima cerebral (SATO; OI; YAMADA, 1999).

Por sua proximidade com a cavidade ventricular, a primeira estrutura afetada é o epêndima, que sofre compressão e o estiramento, e essas alterações podem gerar uma destruição desse epitélio, em pontos isolados ou até seu rompimento total. As alterações do plexo coróide são mais brandas que do epêndima, com distorções das vilosidades, achatamento e vacuolização das células, com formação de inclusões intracelulares e alargamento dos espaços intercelulares (KIEFER et al., 1998). A substância branca também 
sofre as consequências da dilatação ventricular, com diferenças regionais, sendo dependente da idade de instalação da hidrocefalia, que em graus mais acentuados de dilatação ventricular, apresenta perda de seu conteúdo de mielina. $\mathrm{O}$ dano da mielina pode ainda ser resultado do edema, pois o líquido cefalorraquidiano contém enzimas proteolíticas (MABE; SUZUKI; NAGAI, 1990).

Mais tardiamente, ocorre astrogliose, em substituição aos axônios e mielina lesionados (DEL BIGIO; MCALLISTER II, 1999). Em graus mais extremos de dilatação ventricular, o corpo caloso, pode ser totalmente destruído (SHOESMITH; BUIST; DEL BIGIO, 2000). A distorção do encéfalo, leva a um estiramento e a distorção dos vasos cerebrais, além da redução da densidade dos capilares, ocorrendo queda do fluxo sanguíneo cerebral (PORTNOY; BRANCH; CASTRO, 1994).

A hidrocefalia também atinge o neurônio e compromete as sinapses. O corpo neuronal pode apresentar cromatólise e vacuolização e os dendritos podem estar encurtados e reduzidos em número, com menor quantidade de espículas dendríticas. A compressão cortical causa um empacotamento dos neurônios, com redução no tamanho e arredondamento ou achatamento dos neurônios piramidais (EDWARDS et al., 1984, KHAN; ENNO; DEL BIGIO, 2006). Outras estruturas, como o hipocampo, os núcleos da base, o cerebelo e o tálamo, apresentam alterações apenas discretas, com seus neurônios mais preservados.

\subsection{Epidemiologia}

A hidrocefalia constitui um problema de extrema importância para a neurologia clínica e cirúrgica, é uma das doenças mais comuns que acometem o sistema nervoso central (SISTEMA NERVOSO CENTRAL) durante o período neonatal e infância.

As incidências mundiais relacionadas à hidrocefalia congênita variam entre 0,3 a 1,0/1.000 nascimentos. A forma não comunicante, no entanto, alcança índices de 1,0 a 3,0/1.000 (JULIAN-REYNIER et al., 1994). Outra fonte, após estudos realizados em quatro regiões européias, publicou uma prevalência de 4,65/10.000 nascidos vivos (GARNE et al., 2010).

Um levantamento realizado no período de 1997 à 2000, demonstrou que do volume total de cirurgias do Serviço de Neurocirurgia do Hospital das Clínicas da Faculdade 
de Medicina de Ribeirão Preto-USP, vinte e nove por cento eram relativos aos implantes e revisões das derivações liquóricas, sendo que 35\% dos pacientes operados tinham menos de dois anos de idade. Entretanto, os procedimentos cirúrgicos podem representar até $60 \%$ do movimento de um serviço exclusivamente de neurocirurgia pediátrica (JUCÁ et al., 2002).

Informações epidemiológicas do Serviço Nacional de Saúde dos Estados Unidos da América (EUA) registraram mais de 125 mil derivações liquóricas, realizadas no ano de 1995. De todos estes procedimentos 33 mil resultaram na colocação de válvula para o tratamento da hidrocefalia. O país tem um gasto estimado de 100 milhões de dólares anuais, somente com exames para diagnosticar e direcionar de forma adequada a conduta terapêutica, enquanto o gasto envolvido no tratamento da hidrocefalia varia segundo o sistema de derivação escolhido, uso de medicamentos, especialmente os antibióticos, além das cirurgias e do tempo de hospitalização para esses procedimentos (BONDURANT; JIMENEZ, 1995).

\subsection{Hidrocefalia experimental}

Para fins de pesquisa, se fez necessário elaborar métodos de experimentação com o objetivo de entender a fisiopatologia da hidrocefalia e elaborar possíveis técnicas de tratamentos. O caulim é uma substância quimicamente inerte, composto de silicato de alumínio tratado, que causa um processo inflamatório nas meninges, obstruindo a saída do quarto ventrículo, sem lesionar diretamente o parênquima cerebral e sem causar inflamação do espaço subaracnóideo (DEFEO et al., 1979, EDWARDS et al., 1984, HOCHWALD, 1985).

Dixon e Heller (1932) publicaram o primeiro trabalho, utilizando o caulim para produzir hidrocefalia experimental. A injeção de caulim na cisterna magna, tem sido demonstrada como indutor de hidrocefalia não-comunicante que, no estágio agudo, é caracterizada por aumento da pressão intracraniana e progressiva ventriculomegalia. No estágio crônico, a pressão intracraniana normaliza-se e a dilatação ventricular estabiliza-se (BRAUN et al., 1998).

A produção da hidrocefalia por meio da injeção intracisternal de caulim tem sido realizada com sucesso em animais de experimentação (cães, gatos, ratos e camundongos) Um estudo com camundongos realizou a indução da hidrocefalia com êxito, através da 
injeção percutânea de caulim na cisterna magna, tanto em adultos jovens, quanto em animais de sete dias de vida. Os autores estudaram os efeitos da doença avaliando as mudanças comportamentais e histológicas nesses animais (LOPES; SLOBODIAN; DEL BIGIO, 2009).

Diferentes métodos de produção de hidrocefalia experimental apresentam desvantagens em relação ao caulim, pois exigem procedimentos cirúrgicos extensos, podendo ocasionar modificações anatômicas indesejáveis. Muitas vezes há falhas nos resultados, seja por ocasionar hidrocefalia fulminante, seja pelo índice de produção de hidrocefalia ser muito baixo. Além disso, estes métodos não representam o processo patológico natural da maioria dos casos de hidrocefalia, ao contrário do caulim, que produz reação inflamatória semelhante àquela observada em humanos com hidrocefalia, pós-infecção ou hemorragia subaracnóidea (DEFEO et al., 1979, EDWARDS et al., 1984).

Recentemente, tem-se utilizado linhagens de animais geneticamente suscetíveis à hidrocefalia (LEE et al., 2002, VOGEL et al., 2012). Esses animais apresentam hidrocefalia no desenvolvimento intra-uterino impedindo a escolha do inicio da dilatação ventricular, além da não garantia de que as alterações encontradas sejam puramente consequência da hidrocefalia e não da própria malformação genética, reduzindo a possibilidade de estudo dependendo do objetivo da pesquisa.

Devido os fatores presentes nos diferentes métodos citados anteriormente, optamos pela utilização do caulim, por ser mais eficiente, de baixo custo financeiro, não necessitando de procedimentos cirúrgicos e ainda não levar outras alterações, que não sejam resultantes da hidrocefalia.

\subsection{Estresse oxidativo}

O organismo humano sofre ação constante das espécies reativas de oxigênio (EROS) e espécies reativas de nitrogênio (ERNS), geradas em processos inflamatórios, por alguma disfunção biológica ou proveniente dos alimentos. As principais EROS distribuem-se em dois grupos, os radicalares (hidroxila, superóxido, peroxila e alcoxila) e os não-radicalares (oxigênio, peróxido de hidrogênio e ácido hipocloroso). Dentre as ERNS incluem- se o óxido nítrico, óxido nitroso, ácido nitroso, nitritos, nitratos e peroxinitritos. Enquanto alguns deles podem ser altamente reativos no organismo atacando lipídios, proteínas e DNA, outros são reativos apenas com os lipídios. Existem ainda alguns que são pouco reativos, mas apesar 
disso podem gerar espécies danosas. O radical é o mais deletério ao organismo, pois devido a sua meia-vida dificilmente pode ser sequestrado in vivo (HALLIWELL, 2007).

Existe um grande interesse no estudo sobre o efeito do estresse oxidativo devido as descobertas sobre a ação dos antioxidantes. A oxidação é parte fundamental da vida aeróbica e do nosso metabolismo e, assim, os radicais livres são produzidos naturalmente ou por alguma disfunção biológica.

Esses radicais livres cujo elétron desemparelhado encontra-se centrado nos átomos de oxigênio ou nitrogênio que são as EROS, no organismo, encontram-se envolvidos na produção de energia, fagocitose, regulação do crescimento celular, sinalização intercelular e síntese de substâncias biológicas importantes. No entanto, seu excesso apresenta efeitos prejudiciais, tais como a peroxidação dos lipídios e agressão às proteínas dos tecidos e das membranas encontram-se relacionados com várias patologias, tais como artrite, choque hemorrágico, doenças do coração, catarata, disfunções cognitivas, câncer e AIDS, podendo ser a causa ou o fator agravante do quadro geral (HUSAIN et al., 1987).

O estresse oxidativo está presente na hidrocefalia devido à agressão provocada ao parênquima cerebral ocasionada pelas forças de compressão e estiramento. Essa ação leva à lesão tecidual, com produção de radicais livres, principalmente através da peroxidação lipídica, que tem um efeito tóxico nas paredes dos vasos arteriais cerebrais (CANER et al., 1993, FERSTEN et al., 2004).

O excesso de radicais livres no organismo é combatido por antioxidantes produzidos pelo corpo ou absorvidos da dieta. Os antioxidantes são definidos como qualquer substância que, presente em menores concentrações que as do substrato oxidável, sejam capazes de atrasar ou inibir a oxidação de maneira eficaz. Tais substâncias podem agir diretamente, neutralizando a ação dos radicais livres e espécies não radicais, ou indiretamente, participando dos sistemas enzimáticos com tal capacidade (SIES, 1997).

O sistema de defesa antioxidante tem a função de inibir e/ou reduzir os danos causados pela ação deletéria dos radicais livres ou das espécies reativas não radicais. Tais ações podem ser alcançadas por meio de diferentes mecanismos de ação, impedindo a formação dos radicais livres ou espécies não radicais (sistemas de prevenção), impedindo a ação desses ( $\underline{\text { sistemas varredores) }}$ ou, ainda, favorecendo o reparo e a reconstituição das estruturas biológicas lesadas (istemas de reparo) (DEVARAJ et al., 2007).

O mecanismo não enzimático é constituído por grande variedade de substâncias antioxidantes, que podem ter origem endógena ou dietética. A Glutationa é um tripeptídeo essencial, é constituído por três aminoácidos: glicina, ácido glutâmico e cisteína. A 
síntese deste tripeptídeo ( $\gamma$-glutamilcisteinilglicina) ocorre a partir de uma reação catalisada pela enzima $\gamma$-glutamilcisteína sintetase ( $\gamma$-GCS), que utiliza o glutamato e a cisteína para dar origem a $\gamma$-glutamilcisteína, que juntamente com a glicina, através de uma reação catalisada pela glutationa sintetase, irá formar a glutationa (DRINGEN; GUTTERER; HIRRLINGER, 2000). Com ação antioxidante endógena, encontrada em todas as células animais, ela reage com os radicais livres, e pode proteger os tecidos dos danos causados pelo oxigênio singleto e radicais hidróxido e superóxido. No trauma, ocorre uma redução do nível de glutationa, secundária ao estresse oxidativo (HALLIWELL; WHITEMAN, 2004).

Atualmente existem muitas dúvidas a respeito dos mecanismos moleculares responsáveis pela fisiopatologia da hidrocefalia. Diversos estudos tentaram estabelecer relação entre hidrocefalia e estresse oxidativo. No estudo realizado por Mori et al. (1993) em hidrocefalia congênita no cérebro de ratos adultos WIC-HYD, a análise imunoistoquímica revelou redução na enzima superóxido-desmutase (SOD) no epêndima, plexo coróide, e hipocampo. Em hidrocefalia induzida por caulim em ratos, os níveis de peróxido lipídico podem aumentar após a indução da hidrocefalia (CANER et al., 1993). Ratos hidrocefálicos com seis semanas de idade, tiveram um aumento significativo dos níveis de EROS, após o tratamento com um fármaco antioxidante, os animais aumentaram seus níveis de FOXO3a + / - FANCD2 + / -, indicando a proteção contra a morte celular, através do uso do antioxidante e redução significativa da morte dos filhotes hidrocefálicos (LI, X. et al., 2014).

\subsection{Neuroproteção e Edaravone}

A neuroproteção pode ser definida como uma intervenção, não necessariamente farmacológica, mas diretamente ligada aos mecanismos intracelulares da cascata isquêmica, visando o resgate da área de hipoperfusão, ainda viável, circunjacente ao infarto (área de necrose). Engloba as medidas que melhoram o suprimento sanguíneo para o tecido e ainda medidas que aumentam a viabilidade da célula, diante da circulação diminuída (ZAGER; AMES, 1988, ATES et al., 2007).

A droga MCI-186 (3-metil-1-fenil-2-pyrazolin-5-ona) também chamado de Edaravone é um removedor sintético de radicais livres, que foi aprovada no Japão em abril de 2001, para o tratamento de infarto cerebral agudo. Possui um efeito inibitório sobre a 
peroxidação lipídica atuando na remoção de radicais livres e tem sido utilizado para reduzir o dano neuronal, após acidente vascular cerebral isquêmico (ISHIBASHI; YOSHITAKE; ADACHI, 2013, KIKUCHI et al., 2013, DOHARE et al., 2014).

O foco principal das pesquisas com Edaravone é em torno do seu potencial como removedor de radicais livres, tendo um peso molecular baixo ele consegue atravessar facilmente a barreira hematoencefálica (WATANABE; TAHARA; TODO, 2008). Sob condições fisiológicas, com um pH neutro, o Edaravone está presente em forma aniônica ou seja, sua metabolização no organismo ocorre através de um processo de transferência de elétrons. Estes são liberados do Edaravone e podem eliminar espécies de radicais contendo um elétron livre, como um radical peróxido-lipídico, que é formado após a extração de um próton de radicais livres a partir de um ácido graxo insaturado. (HIGASHI et al., 2006).

O benefício terapêutico do Edaravone pode ser mais do que sua atividade antioxidante. Por ele ter uma farmacologia multi-alvo faz com que tenha uma capacidade de regular outras vias de sinalização. Por exemplo, pesquisas recentes têm sugerido que Edaravone pode suprimir a morte neuronal (YOSHIDA et al., 2006), neutralizar neurotoxicidade na microglia (BANNO et al., 2005) e reduzir a inflamação de longa duração (ZHANG et al., 2005).

Mediante o uso do Edaravone, atenuando nos efeitos deletérios ocasionados pela cascata isquêmica, tem mostrado que se pode evitar o desenvolvimento de edema na sequência de um acidente vascular cerebral, através da inibição da astrogliose e expressão do fator de crescimento endotelial vascular (ISHIKAWA et al., 2007).

Um estudo com modelo de isquemia e reperfusão em roedores, forneceu evidências adicionais de que o Edaravone reduziu os danos causados pela isquemia (WU et al., 2000).

Outros estudos tem também demonstrado que Edaravone pode inibir a lipoxigenase, uma enzima responsável pela oxidação lipídica (HIGASHI et al., 2006) mas também pode suprimir diretamente a oxidação de lipoproteínas de baixa densidade (YOSHIDA et al., 2006).

Usando uma população de pacientes com acidente vascular cerebral, pesquisadores estudaram os efeitos do Edaravone sobre o resultado funcional. Uma diferença importante a notar nesse estudo, é o tempo de duração da internação hospitalar e melhora na paralisia motora. A análise estatística mostra que houve uma redução maior da média do tempo de hospitalização e reabilitação motora no grupo tratado com Edaravone quando comparado com o grupo de não tratado (OHTA et al., 2009). 
Um estudo sobre a oclusão da artéria carótida interna em pacientes também mostrou a eficácia do Edaravone. A mortalidade na fase aguda pós-oclusão diminuiu no grupo tratado, sendo $20 \%$ de mortalidade comparada a $45 \%$ de mortalidade do grupo não tratado. Considerando a natureza devastadora do acidente vascular estes resultados são significativos (TOYODA et al., 2004).

Além da isquemia cerebral, foi comprovado seu efeito neuroprotetor em outras doenças neurológicas, como encefalopatia neonatal (NAKAMURA et al., 2008) hemorragia intracerebral aguda (NOOR et al., 2005),(YAGI et al., 2009), hemorragia subaracnóidea (MUNAKATA et al., 2009) esclerose lateral amiotrófica (ITO et al., 2008), lesão cerebral traumática (ITOH et al., 2009), lesão medular (WANG et al., 2013), epilepsia (KAMIDA et al., 2009). Em um modelo experimental de trombose cerebral e tratamento com Edaravone, este foi associado à recuperação funcional de hemiparesia, e redução da área de infarto (INOUE et al., 2014). 
2. JUSTIFICATIVA 
Como nem todos os pacientes podem ser submetidos ao tratamento cirúrgico, com derivações liquóricas imediatamente após o diagnóstico, seja por apresentarem condições clínicas desfavoráveis ou por apresentarem ainda dilatação ventricular inicial, drogas neuroprotetoras estão sendo testadas, na tentativa de redução dos danos teciduais até o tratamento definitivo, ou mesmo para reforçar a recuperação completa após a instalação de um shunt. 
3. OBJETIVOS 
Avaliar a resposta neuroprotetora do Edaravone na hidrocefalia experimental, através de:

- Testes comportamentais: campo aberto (para avaliação do desenvolvimento sensoriomotor) e labirinto aquático de Morris (para avaliação da memória e aprendizagem).

- Ressonância magnética do encéfalo: para determinação do grau de ventriculomegalia (razão ventricular) e grau de mielinização cerebral (transferência de magnetização).

- Histologia: hematoxilina e eosina (citoarquitetura geral) e Solocromo-cianina (medição do corpo caloso, processo de mielinização).

- Imunoistoquímica: GFAP (avaliação da astrogliose), Ki-67 (quantificação das células em divisão mitótica), caspase-3 (avaliação da presença de células em apoptose), lectina (reação microcitária).

- Bioquímica: medir a capacidade total de antioxidantes presentes no plasma, dosagem da glutationa peroxidase presente no tecido encefálico, e dosagem do malondialdeído para medir a peroxidação lipídica. 
4. MATERIAIS E MÉTODOS 
O presente projeto está de acordo com os Princípios Éticos adotados pelo Colégio Brasileiro de Experimentação Animal (COBEA), protocolo n ${ }^{\circ}$ 114/2012 e aprovados pelo comitê local (CETEA - Faculdade de Medicina de Ribeirão Preto da USP).

São utilizadas ninhadas de ratos machos da linhagem Wistar, com sete dias de vida, oriundas do Serviço de Biotério da Prefeitura do Campus Administrativo de Ribeirão Preto, em número suficiente para composição dos grupos experimentais. Cada ninhada é constituída pela rata-mãe e 8 a 10 filhotes, transportados em uma única caixa de alojamento, no dia do nascimento, para o Biotério da Cirurgia Experimental do Departamento de Cirurgia e Anatomia da Faculdade de Medicina de Ribeirão Preto. Foram necessários 50 ratos para realização de todos os testes e análises. Foram usadas 5 ratas-mãe para cuidar e amamentar todas as ninhadas (1 rata por caixa-alojamento), porém, essas ratas não participaram diretamente do projeto. Durante a permanência dos animais no Biotério, a dieta padrão de laboratório para roedores e água será oferecida ad libitum às mães. Os filhotes em fase de desmame também tiveram acesso à dieta e à água.

\subsection{Indução da hidrocefalia}

Com 7 dias de idade, os filhotes foram escolhidos aleatoriamente e submetidos à indução da hidrocefalia pelo método da injeção intracisternal de caulim, sob anestesia inalatória com isoflurano ou mantidos sem intervenção para utilização como controle normal. Para indução da hidrocefalia, cada animal foi posicionado por um auxiliar, que segura à cabeça com uma mão e o corpo com a outra mão, flexionando o pescoço do animal, deixando livre a região cervical dorsal. Através da palpação, foi identificado o espaço entre a margem posterior do forame magno, no osso occipital, e a borda cranial do arco dorsal da primeira vértebra cervical (figura 1). Com uma agulha odontológica Mise 0,3 de bisel curto, foi realizada uma punção suboccipital, e injetado, por injeção percutânea lenta, $0,04 \mathrm{ml}$ de uma suspensão de caulim (Merck®) a 15\% em água destilada, esterilizada em autoclave. A seguir, os animais foram recolocados em sua caixa- alojamento de origem, retornando ao Biotério. 


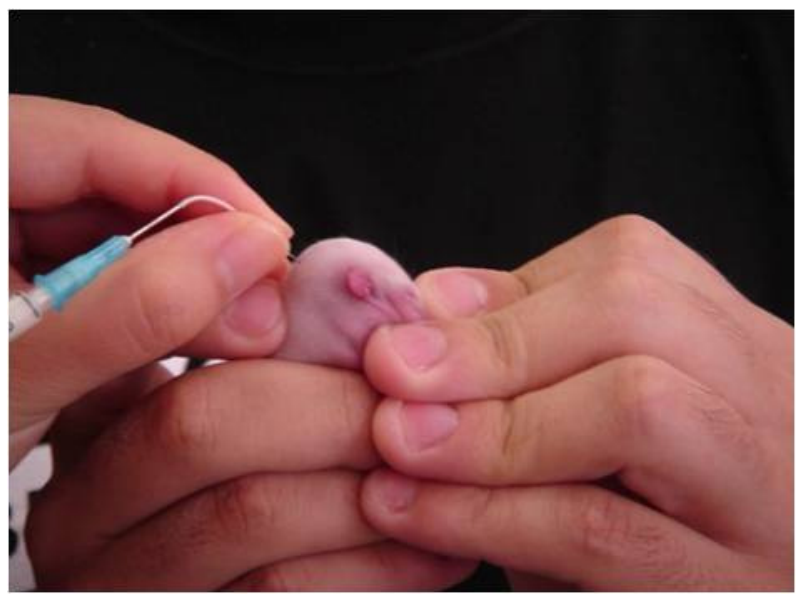

Figura 1 - Indução da hidrocefalia com posicionamento do rato por um auxiliar e punção percutânea da cisterna magna e injeção do caulim pelo pesquisador.

\subsection{Formação dos grupos experimentais}

- Grupo Controle (C): Animais sacrificados com 21 dias de vida $(\mathrm{n}=10)$.

- Grupo Hidrocefálico (HNT): Animais sacrificados com 14 dias após a injeção de caulim (21 dias de vida) $(\mathrm{n}=20)$.

- Grupo Hidrocefálico Tratado (HTE): Animais que recebem diariamente injeção intraperitoneal de Edaravone $(2 \mathrm{mg} / \mathrm{kg})$. Esses animais são sacrificados com 14 dias após a injeção de caulim e tratamento (21 dias de vida) $(\mathrm{n}=20)$.

Todos os animais injetados foram observados diariamente quanto a possíveis alterações clínicas (perda de peso e desidratação, alterações da marcha e da consciência, negligência com a higiene). Em caso de percepção de sofrimento e lesão neurológica grave, perda de peso importante ou desidratação que não responde à hidratação com injeção subcutânea de soro fisiológico, o rato foi sacrificado com dose excessiva de anestésico, não sendo usado para o experimento. 


\subsection{Estudos comportamentais}

Os animais foram pesados diariamente e seu comportamento geral na caixaalojamento foi avaliado, tanto individualmente (exploração do ambiente, mobilidade no espaço), quanto na interação com os outros membros do grupo.

Para estudo do desenvolvimento sensoriomotor, o comportamento deambulatório foi avaliado a cada 2 dias pelo teste de campo aberto (Open Fiel), a partir do dia 6, após a injeção (P6). Cada animal foi observado individualmente em uma arena de acrílico transparente de $60 \mathrm{~cm}$ de comprimento e $45 \mathrm{~cm}$ de altura. Seu tempo foi cronometrado por 2 minutos, sendo avaliados, os cuidados com a higiene, exploração do ambiente e marcha de acordo com a escala: 4 = alerta, com exploração e marcha normal; $3=$ discretamente letárgico, com atividade reduzida, mas com marcha normal quando estimulado; 2 = cifótico, caminha, mas a marcha tem base alargada, instável ou atáxica; 1 = mal consegue andar, mas ainda se alimenta; $0=$ próximo da morte ou eutanasiado. A arena foi limpa com sabão neutro diluído em água, entre as observações de diferentes ninhadas de animais.

Para o estudo da memória e aprendizagem espacial, os ratos foram submetidos ao teste com labirinto Aquático de Morris modificado (water maze). O aparelho é composto por uma piscina circular (100 $\mathrm{cm}$ de diâmetro, $50 \mathrm{~cm}$ de altura) e uma plataforma transparente (34 $\mathrm{cm}$ de altura, $8 \mathrm{~cm}$ de diâmetro) posicionada $2 \mathrm{~cm}$ abaixo da superfície da água. A temperatura da água da piscina foi controlada em aproximadamente $22^{\circ} \mathrm{C}$, sendo dividido em duas fases (adaptação e aprendizagem espacial). A fase de adaptação e treinamento foi realizada no dia correspondente ao $9^{\circ}$ dia pós-indução da hidrocefalia (P09), no qual os ratos tinham 60 segundos livres para nadar na piscina, sem a plataforma. A seguir, a plataforma foi introduzida no tanque, posicionada em um quadrante (o tanque é dividido aleatoriamente em 4 quadrantes). O treinamento era feito em quatro séries, sendo que em cada uma o animal era colocado na água voltado para um dos 4 pontos cardeais. Esse cuidado era feito para que o rato memorizasse a parede iluminada como ponto de referência para localizar a plataforma camuflada sob a superfície aquática, e não o encontro ao acaso da mesma pela natação em linha reta. A sala que abriga o tanque é totalmente escura, exceto por uma pequena fonte luminosa fixada próxima a um dos lados externos do tanque (norte), para que o animal identifique o ponto de referência a ser memorizado. $\mathrm{O}$ teste foi então, aplicado nos dias P10 e P11 pós-indução, com o animal sendo posicionado 
em cada sessão, voltado para um dos pontos cardeais (com 4 sessões sequenciais), em 2 turnos em um mesmo dia. O tempo limite para o animal alcançar a plataforma e ser considerado um acerto é de 60 segundos. No final de cada sessão o animal foi colocado na plataforma para descanso de 15 segundos, após foi recolocado junto à parede da piscina, para iniciar uma nova sessão. Foi cronometrado o tempo gasto do ponto de partida até o encontro da plataforma de descanso. O tempo médio de cada turno diário, foi calculado pela média do tempo gasto para o encontro da plataforma em cada uma das 4 sessões. Se o animal não encontrasse a plataforma até um tempo limite de $60 \mathrm{seg}$, seria colocado na plataforma para descanso de $30 \mathrm{seg}$, e o tempo considerado para execução da tarefa naquela sessão seria de $60 \mathrm{seg}$. No final do teste, o animal foi seco com uma toalha macia e mantido em uma caixa aquecida, e então, recolocado junto a mãe e os outros filhotes da ninhada. Entre cada animal examinado, foi recolhida com uma peneira, toda sujeira (dejetos animais sólidos e partículas da cama de maravalha) visível na água da arena.

\subsection{Estudos por ressonância magnética}

Os animais com hidrocefalia e seus controles, no $13^{\circ}$ (dia) pós-indução, foram levados para aquisição de imagens por ressonância magnética (RM) do encéfalo, sob anestesia com quetamina $10 \%$ e xilasina $10 \%$ intraperitoneal (nas doses de 0,1 e $0,05 \mathrm{mg} / 100 \mathrm{~g}$ de peso corporal), em aparelho com campo de 3T, como demonstrado na (figura 2).

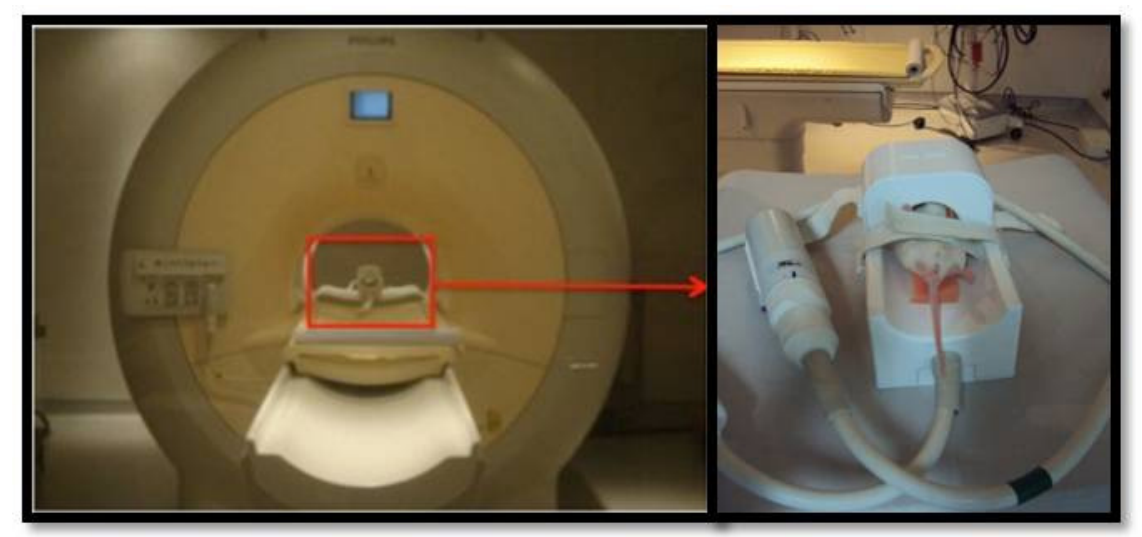

Figura 2 - Posicionamento do animal no gantry do aparelho de ressonância magnética de 3T, em bobina própria para pequenos roedores, para aquisição das imagens no $13^{\circ}$ dia de vida. 
A aquisição de MR foi realizada em um scanner 3T (Philips, Achieva) usando uma bobina indicada somente para pequenos roedores. $\mathrm{O}$ protocolo incluiu uma imagem 3D ponderada em T2 e duas sequências de MTR/3D quase idênticas (figura 3). A sequência T2 A- 3D ponderada foi escolhido para aumentar o contraste entre o fluido cerebrospinal e tecido cerebral, com alta resolução espacial. Usamos a transferência de magnetização pré- pulso definido como padrão "na ressonância" pulso no scanner MR Philips (composto de 121 pulsos de RF com $90^{\circ}$ e 4 elementos retangulares com uma duração de $275 \mathrm{mS}$ cada). A partir de ambas as imagens, o valor MTR em cada pixel é calculado usando a seguinte expressão:

MTR [\%] = $($ PIwoMT - PIwMT $) \cdot 100$ / PiwoMT; onde, PIwMT e PIwoMT representam a intensidade dos pixels na imagem com a transferência de magnetização prépulso.

\begin{tabular}{|c|c|c|}
\hline Sequências & 3D T2 & 3D MTR \\
\hline Tempo do echo & $60 \mathrm{~ms}$ & $11 \mathrm{~ms}$ \\
\hline Tempo de repetição & $1500 \mathrm{~ms}$ & $23 \mathrm{~ms}$ \\
\hline Plano & Sagital & Sagital \\
\hline Dimensões do voxel & $0.3 \mathrm{~mm} \times 0.3 \mathrm{~mm} \times 0.3 \mathrm{~mm}$ & $0.3 \mathrm{~mm} \times 0.3 \mathrm{~mm} \times 0.3 \mathrm{~mm}$ \\
\hline Espessura & $0.3 \mathrm{~mm}$ & $0.3 \mathrm{~mm}$ \\
\hline
\end{tabular}

Figura 3 -Detalhes sobre os parâmetros de sequência.

A segmentação manual dos ventrículos laterais e total do cérebro foi realizada no plano coronal em imagem 3D- T2W usando o STARTX software for Linux CYGWIN 4.1.10 version. A razão ventricular (RV) foi calculada dividindo-se a área dos ventrículos laterais pela a área total do cérebro, como se segue:

$\mathrm{RV}=\mathrm{AVL} / \mathrm{AVL}+\mathrm{AC}$, onde:

$\mathrm{AVL}=$ área do ventrículo lateral (colorido em vermelho, na figura 3)

$\mathrm{AC}=$ área do cérebro (colorido em verde, na figura 3)

O MTR foi também obtido no plano coronal médio usando-se a imagem do cérebro total gerado na segmentação e o mapa MTR. Os dados de transferência de magnetização foram obtidos através de demarcações de áreas de interesse (ROI), uma na região dorsal e a outra na região ventral do ventrículo lateral (figura 4). 


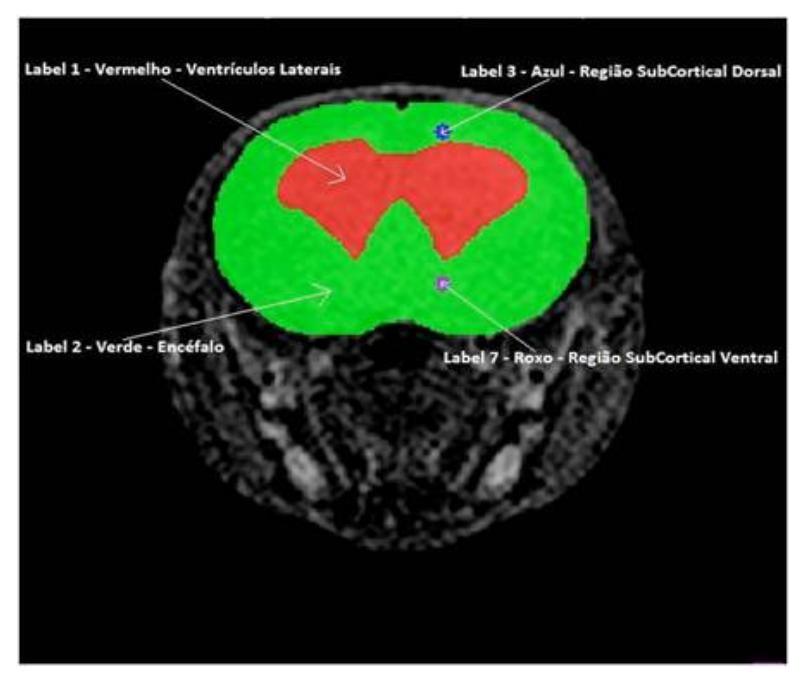

Figura 4 - A. Imagem obtida por RM, sequência em T2, em reconstrução coronal média, com delimitação das áreas de interesse (ROI) (Azul= ROI dorsal do ventrículo lateral / Violeta=ROI ventral do ventrículo lateral) que foram usadas para quantificação da mielina, e delimitação das áreas do encéfalo e dos ventrículos laterais para cálculo da razão ventricular (Área vermelha= ventrículo lateral / Área verde= encéfalo total).

\subsection{Coleta das amostras: perfusão cerebral e dissecção de estruturas}

Ao final dos tempos experimentais, os animais de cada grupo foram anestesiados profundamente com injeção intraperitoneal de quetamina $10 \%$ e xilazina $10 \%$ (nas doses de 0,1 e $0,05 \mathrm{mg} / 100 \mathrm{~g}$ de peso corporal). Após posicionamento na mesa cirúrgica, em decúbito dorsal, foi realizada uma ampla incisão em "Y" em cada animal, no tórax, das duas clavículas até o apêndice xifóide, e, no abdômen, incisão mediana, xifo-púbica.

Nos animais selecionados para análise histológica e imunoistoquímica (metade de cada grupo), uma agulha $21 \mathrm{G}$ era introduzida na ponta do ventrículo esquerdo e canulada até a raiz da aorta, sendo iniciada a perfusão transcardíaca com solução salina, após uma pequena incisão na aurícula direita, até o clareamento do líquido de saída (cerca de $1 \mathrm{ml} / \mathrm{g}$ de peso do animal), com auxílio de uma bomba de perfusão peristáltica (Fisher Scientific). A seguir, os animais foram decapitados e seus encéfalos retirados em bloco, através de uma craniectomia de vértex, subdivido no plano coronal, em uma porção anterior e outra posterior, tomando-se como referencial o quiasma óptico, depois imersos em uma solução fixadora de paraformaldeído a $3 \%$ em tampão fosfato $0,1 \mathrm{M}(\mathrm{pH} 7,3-7,4)$, por 24 horas à temperatura de $4^{\circ} \mathrm{C}$, quando é trocada por uma solução de paraformaldeído $3 \%$ fresca, permanecendo nesta solução fixadora por mais 7 dias à mesma temperatura. Nos animais selecionados para análise 
bioquímica (metade de cada grupo), foi puncionada a ponta do ventrículo cardíaco esquerdo com uma agulha $21 \mathrm{G}$, introduzindo-se a mesma até a raiz da aorta, assim aspirou-se $2 \mathrm{ml}$ de sangue total e armazenou-se em 1 frasco tipo vacutainer® com heparina, para a dosagem de antioxidantes presentes no plasma, em seguida iniciou-se a perfusão cardíaca. Seus foram retirados e divididos no plano sagital, congelados em nitrogênio líquido e mantidos em freezer $-80^{\circ} \mathrm{C}$ para posteriores dosagens de antioxidantes totais, glutationa-peroxidase e malondialdeído.

\subsection{Análise bioquímica}

As amostras do encéfalo previamente congeladas foram diluídas 1:3 em tampão homogeneizadas com um homogenizador de tecidos (Polytron - Kinematica PT 1600E). As amostras de sangue, após a formação do coágulo, foram centrifugadas a 2.000 x g por $4^{\circ} \mathrm{C}$ por 15 min, para separação do plasma, que foi estocado a $-80^{\circ} \mathrm{C}$. Todas as amostras assim obtidas (plasma e tecido) foram submetidas aos testes bioquímicos com uso de kits, seguindo a orientação do fabricante.

O ensaio “Antioxidant Assay Kit" (Cayman- n 709001) foi usado para medir a capacidade total de antioxidantes presentes no plasma. As amostras de plasma previamente armazenadas foram descongeladas e diluídas 1:20 com o tampão apropriado (kit). A seguir foram distribuídas, em duplicata, em placa de 96 poços, ao lado das diluições do padrão. Após, segue-se a pipetagem dos outros reagentes do kit leitura imediata em medida de absorbância de $750 \mathrm{~nm}$ conforme orientações do fabricante.

Para a dosagem da Glutationa Peroxidase presente no tecido encefálico, foi usado o "Glutathione Peroxidase Assay Kit (GPx)" (Cayman - n 703102). As amostras foram descongeladas e centrifugadas a $10.000 \mathrm{~g}$ a $4^{\circ} \mathrm{C}$ por $15 \mathrm{~min}$. As diluições da solução-padrão e

das amostras foram distribuídas em duplicata na placa de 96 poços. Os reagentes adicionais do kit foram pipetados. A atividade do Gpx foi calculada a partir da diferença por minuto e a leitura da placa na leitora foi realizada com uma medida de absorbância de $340 \mathrm{~nm}$ conforme orientações do fabricante.

Para dosagem do malondialdeído (MDA) (medida da peroxidação lipídica), foi usado o "TBARS Assay Kit" (Cayman-n¹009055). O tecido cerebral previamente 
homogeneizado foi descongelado e centrifugado a 1.600 g por $10 \mathrm{~min}$ a $4^{\circ} \mathrm{C}$. O sobrenadante resfriado e pipetado em duplicatas em placa de 96 poços a seguir foi acrescentado os demais reagentes do kit. Após o tempo de pausa para as reações químicas, a placa foi lida em leitora com absorbância de 530-540 nm conforme orientações do fabricante.

\subsection{Histoquímica e imunoistoquímica}

Os encéfalos foram desidratados em soluções crescentes de álcool (50\% a 100\%), diafanizados em xilol e emblocados em parafina, e cortados coronalmente em micrótomo rotativo em secções de $5 \mu \mathrm{m}$ de espessura e os cortes estendidos em lâminas histológicas.

Para análise por histoquímica, as lâminas foram mantidas em estufa $\left(60^{\circ} \mathrm{C}\right)$ por uma hora para derretimento da parafina. A seguir, os cortes foram submetidos ao processo de desparafinização, seguidos de banhos sequenciais de xilol, álcool em concentrações decrescentes e água; posteriormente, foram corados com hematoxilina e eosina ou solocromocianina (cada amostra foi corada com ambas as colorações). Foi observada (hematoxilina e eosina) a citoarquitetura geral, distribuição das estruturas e densidade celular, enquanto para a coloração por solocromo-cianina, foi observado o grau de mielinização da substância branca periventricular e aplicado um "score" de 0 a 2, para avaliar a tonalidade em azul. Quanto maior a tonalidade em azul, maior a pontuação do score, e após este processo foram feitas as medidas da espessura do corpo caloso.

Para imunoistoquímica, as lâminas foram mantidas em estufa a $60^{\circ} \mathrm{C}$, por 30 min, e desparafinizadas em banhos sequenciais de xilol e álcool. Foram realizados estudos por imunoistoquímica para GFAP (glial fibrillary acidic protein) para avaliação da distribuição e aspecto morfológico da astroglia, Ki-67 para avaliação da matriz germinativa no ângulo externo do ventrículo lateral, capase- 3 para avaliação da presença de lesão por apoptose e lectina para avaliação da reação microcitária. Após a recuperação antigênica, quando indicado, pelo método de acidificação e aquecimento (citrato de sódio em micro-ondas), foi realizado o bloqueio da peroxidase endógena com peróxido de hidrogênio a 3\% em metanol. Posteriormente, foi feito o bloqueio com soro adequado a $10 \%$ em PBS, por 30 minutos em câmara úmida. Logo após, os cortes foram incubados "overnight" à temperatura de $4^{\circ} \mathrm{C}$ com 
o anticorpo primário [anti-GFAP (DAKO Z0334, Dinamarca), anti-Ki67 (Santa Cruz sc23900), anti-caspase-3 (Santa Cruz sc-7148), Lectina (L2140- BS-I sigma)], em diluições apropriadas, previamente testadas. Retirado o anticorpo primário, foi adicionado o anticorpo secundário apropriado (anticorpo biotinilado de cabra anti-coelho - Santa Cruz Biotechnology SC-2040, ou anti-camundongo - Santa Cruz Biotechnology SC-2039) diluído 1:300 em BSA (para lectina o anticorpo secundário é dispensado). Após, foram incubados com o anticorpo terciário estreptavidina conjugada com HRP (BioLegend cat.405210) diluído 1:160 em PBS. A seguir, foram revelados com DAB (3,3'- diaminobenzidina - Sigma). Por fim, as lâminas foram submetidas à contracoloração com hematoxilina, lavadas em água corrente, desidratadas por uma série sequencial de banhos crescentes de álcool e xilol, e recobertas por lamínulas montadas com Permount ${ }^{\circledR}$. Observação: para a imunoistoquímica, os cortes foram estendidos em lâminas histológicas silanizadas.

\subsection{Documentação fotográfica}

A documentação fotográfica das lâminas histológicas foi realizada no laboratório de Neurologia Aplicada e Experimental do Departamento de Neurociências e Ciências do Comportamento da Faculdade de Medicina de Ribeirão Preto - USP, através de um microscópio de luz AxiosKop2 plus (Carl Zeiss) e uma câmera digital AxioCam Hrc (Carl Zeiss) acoplados a um computador Pentium II equipado com o software Axio Vision 3.1, utilizando a objetiva de 40x, com óleo de imersão.

Para as lâminas coradas com hematoxilina e eosina foi fotografado o corpo caloso a matriz germinativa o córtex cerebral dorsal e a cápsula externa, para posterior avaliação da citoarquitetura. Nas lâminas coradas com solocromo-cianina, foi fotografada a região do corpo caloso para medição de sua espessura. E também através de um confronto visual foi possível aplicar um "score" de 0 a 2, sendo 0: tonalidade fraca em azul; 1: tonalidade média em azul e 2: tonalidade forte em azul para a avaliação da mielinização.

Para as lâminas imunomarcadas por GFAP, foram fotografadas as regiões do corpo caloso e da matriz germinativa, as imagens foram usadas para as contagens dos astrócitos reativos, e para classificação da reação astroglial, através de um confronto visual foi 
aplicado um "score" de 0 a 2, sendo 0: ausência de astrócitos reativos; 1: astrócitos reativos com prolongamentos finos e delicados e 2: astrócitos reativos com prolongamentos grossos.

Para as lâminas imunomarcadas com Ki67, foi fotografada apenas a região da matriz germinativa no ângulo externo do ventrículo lateral (área de intensa proliferação celular), onde foi feita a contagem das células imunomarcadas em divisão mitótica.

Já nas lâminas imunomarcadas por caspase-3 foi feito uma varredura por toda a extensão do corpo caloso e córtex dorsal cerebral, e contada todas as células imunomarcadas destas regiões, sendo fotografadas algumas células, apenas para documentação o mesmo procedimento foi realizado em lâminas imunomarcadas com lectina.

Para a realização da contagem de células marcadas na imunoistoquímica, bem como para medida da espessura do corpo caloso, foi utilizado o programa de computador IMAGEJ versão 1.42q, distribuído pelo National Institutes of Health (NIH), USA.

\subsection{Análises estatísticas}

Todos os dados são apresentados como médias $(\mathrm{x}) \pm$ erro padrão da média (SEM). Para análise de dois grupos foi usado o teste t-Student e para três ou mais grupos a análise de variância (ANOVA), seguida pelo pós-teste de Tukey, quando indicado, para dados paramétricos, e teste de Mann-Whitney U, com pós-teste de Dunn, para dados nãoparamétricos. As diferenças estatísticas são consideradas quando $\mathrm{p}<0.05$. Foi utilizado um programa estatístico para ambiente Windows, BioEstat versão 5.0, desenvolvido e distribuído pelo Instituto de Desenvolvimento Sustentável Mamirauá, com apoio do Ministério da Ciência e Tecnologia e para alguns teste foi usado o programa GraphPadPrismversion 5.0 (GraphPad Software, Inc. 2007). 
5. RESULTADOS 


\subsection{Avaliação do peso corporal}

Todos os animais foram pesados diariamente, desde o P0 (7 dias de vida), até o final do experimento no P14 (21 dias de vida). No P0 não houve diferença de peso entre os vários grupos experimentais.

O grupo C apresentou um ganho de peso semelhante ao grupo HNT, a partir do sexto até o oitavo dia pós-indução (P6 a P8) com (p<0,05). A partir do P9 o ganho de peso corporal foi similar nos três grupos experimentais (figura 5).

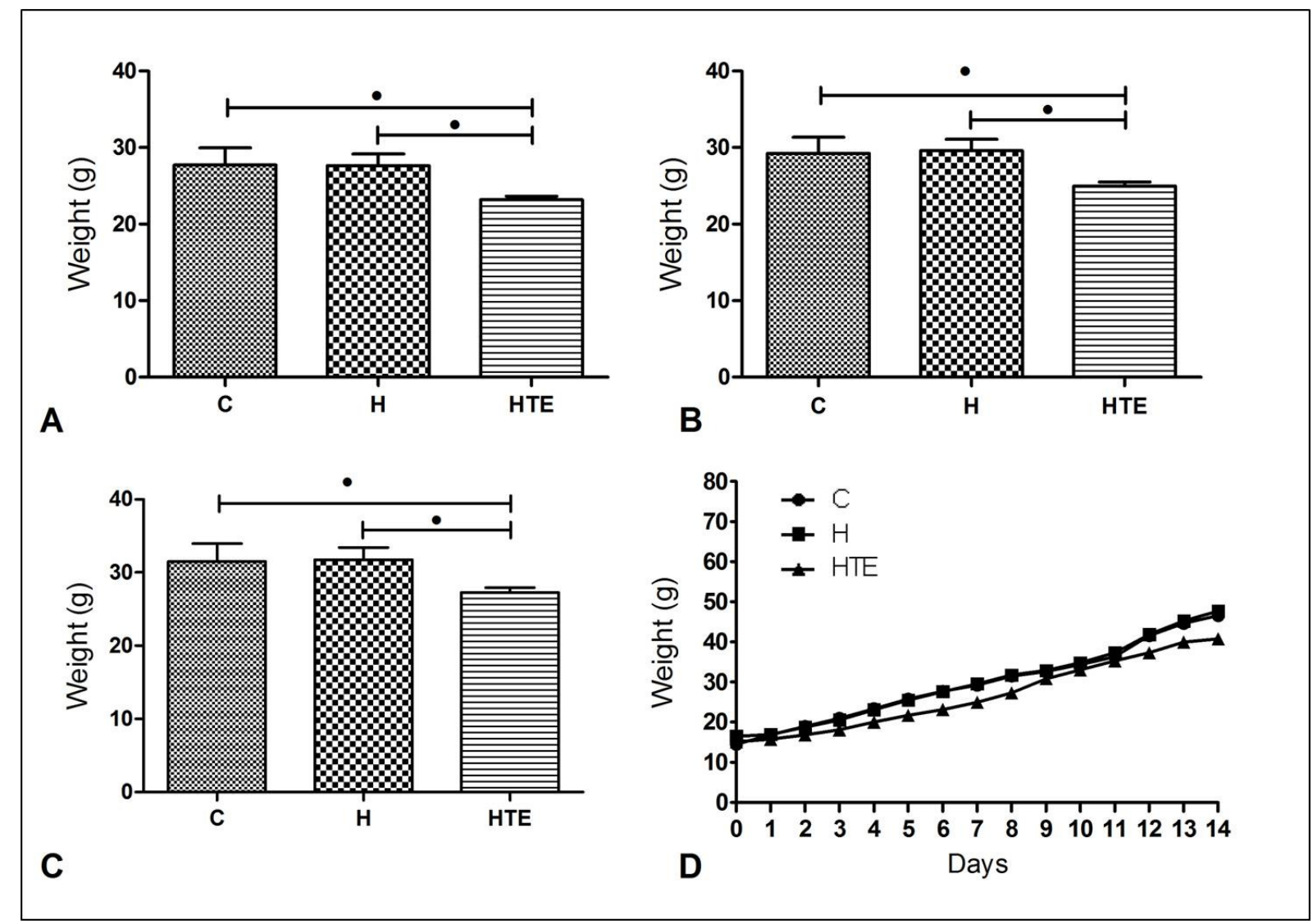

Figura 5 - Gráfico representativo das médias dos pesos diários, dos ratos dos diferentes grupos experimentais. Grupos: C: controle, H: hidrocefálico sem tratamento e HTE: hidrocefálico tratado com edaravone A: P6, B:P7, C:P8, D: evolução das médias de peso diários dos animais de diferentes grupos experimentais.Os animais controles (C) apresentavam um ganho de peso semelhante aos animais do grupo HNT de P6 a P8 $(\mathrm{p}<0,05)$. 


\subsection{Avaliação comportamental geral}

Durante o manejo dos animais para a pesagem diária e limpeza da caixa (troca da cama de maravalha) foi observado o comportamento geral dos animais, o grupo HTE eram visivelmente mais ativos que os animais hidrocefálicos não tratados, interagindo com o ambiente e explorando-o de forma espontânea. Além de estarem mais atentos, apresentavam uma melhor interação entre si, demonstrando comportamentos naturais mais frequentes, como de luta e asseio corporal.

\subsection{Avaliação comportamental com testes específicos}

\subsubsection{Teste de campo aberto (open field)}

No teste de Open Field, realizado no P06, todos os grupos experimentais não apresentaram diferenças significativas. Entretanto, no P08, os animais do grupo HTE exibiram uma melhor exploração do ambiente e padrão de marcha menos alargado quando comparado com os grupos $\mathrm{C}$ e HNT, com diferença estatística significativa $(\mathrm{p}<0,05)$. No teste de P10 os animais do grupo $\mathrm{C}$ apresentavam um comportamento semelhante com os animais do grupo HTE, havendo diferença estática quando comparados com os animais do grupo HNT $(\mathrm{p}<0,05)$. Em P12 e P14, os animais dos grupos HTE e C se mostravam maior exploração do ambiente, marcha normal e cuidados com a higiene, em relação aos animais do grupo HNT, havendo uma diferença estatística $(\mathrm{p}<0,05)$ (figura 6). 


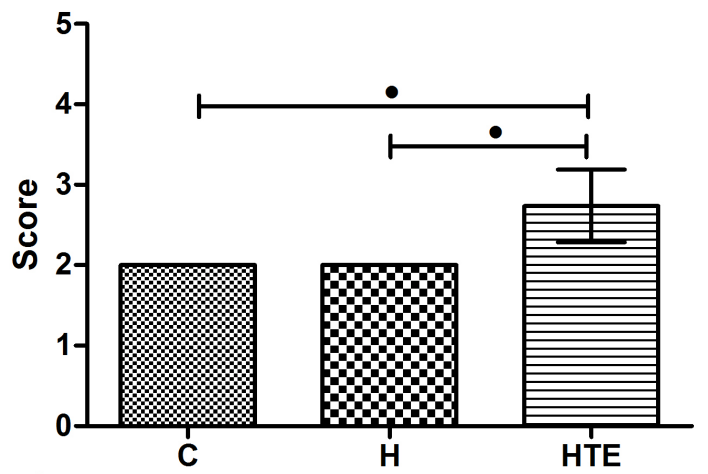

A
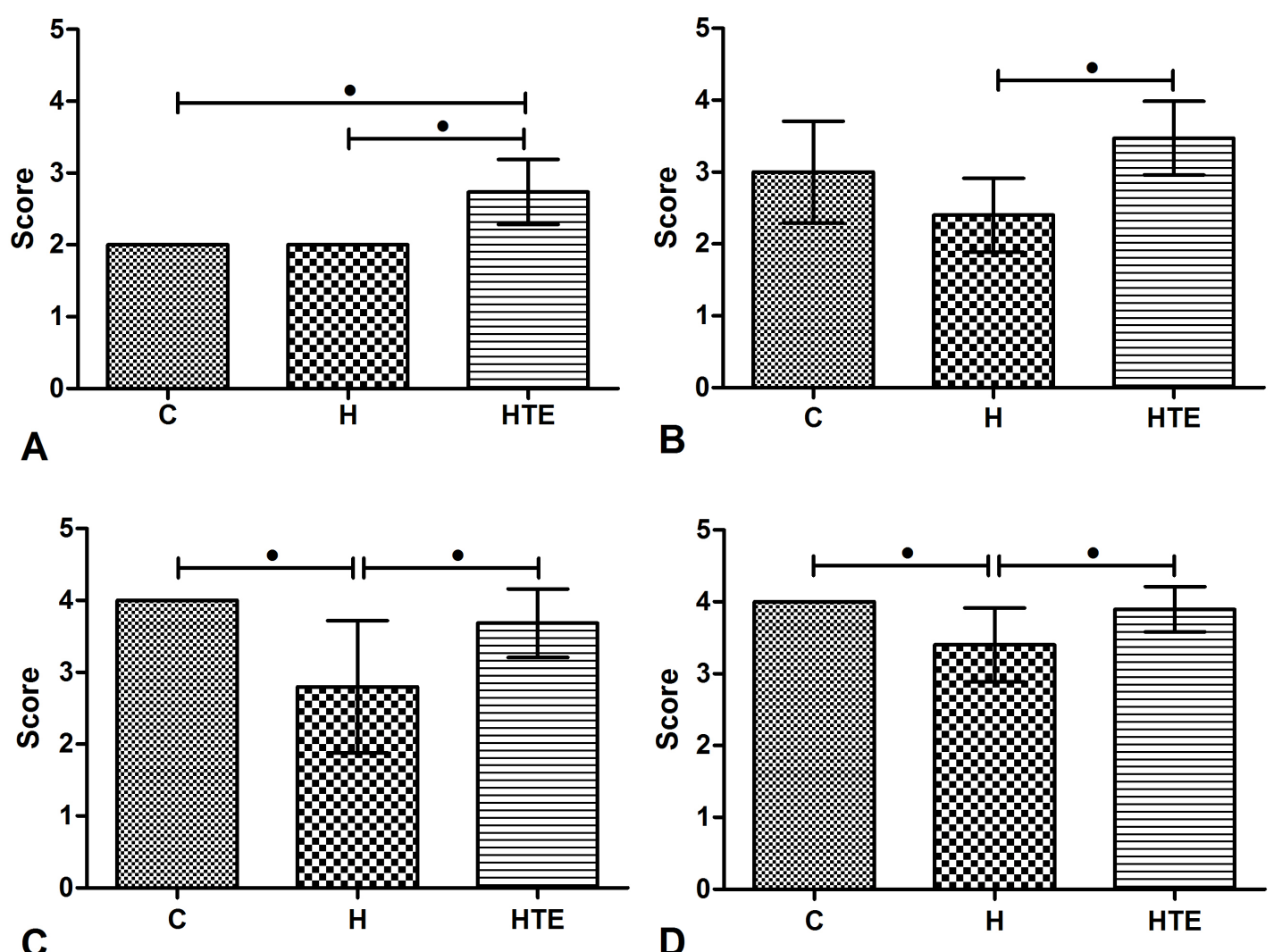

Figura 6: Gráficos representativos do desempenho no teste de campo aberto (open field). Grupos: C: controle, $\mathrm{H}$ : hidrocefálico sem tratamento e HTE: hidrocefálico tratado com edaravone A: P8, B: P10, C:P12, D: P14. Os animais do grupo HTE, mostravam maior capacidade funcional, quando comparados com os outros grupos $(\mathrm{p}<0,05)$.

\subsubsection{Labirinto aquático de morris (water maze)}

Durante a realização do teste labirinto aquático de Morris, realizado em P10, podemos observar que, no período da manhã, os animais do grupo HTE obtiveram uma média menor de tempo para atingir a plataforma quando comparados com os animais do grupo HNT e C sem diferenças significativas. No período da tarde, todavia, pode-se observar um melhor desempenho dos animais tratados com Edaravone que conseguiram atingir a plataforma apresentando diferenças estatísticas significantes ( $p<0,05),(C: x=51,60 \pm 5,07$; HTE: $x=45,34$ $\pm 7,80$; HNT: $\mathrm{x}=53,17 \pm 8,35$ ). No P11 durante o teste do período da manhã, os animais do grupo HNT tiveram uma média de tempo maior do que os animais dos grupos HTE e C, mostrando que na execução do teste, eles demoravam mais tempo para chegar à plataforma, enquanto os animais dos grupos HTE e C foram aprendendo e memorizando o caminho para 
chegar à plataforma com diferença estatística $(\mathrm{p}<0,05),(\mathrm{C}: \mathrm{x}=34,25 \pm 12,40 ;$ HTE: $\mathrm{x}=38,68$ $\pm 13,05 ;$ HNT: $x=51,60 \pm 5,97)$. Já no período da tarde, a média de tempo dos três grupos experimentais eram semelhantes $(C: x=34,70 \pm 12,55$; HTE: $x=41,36 \pm 14,06$; HNT: $x=43,07$ $\pm 15,46$ ) (figura7).

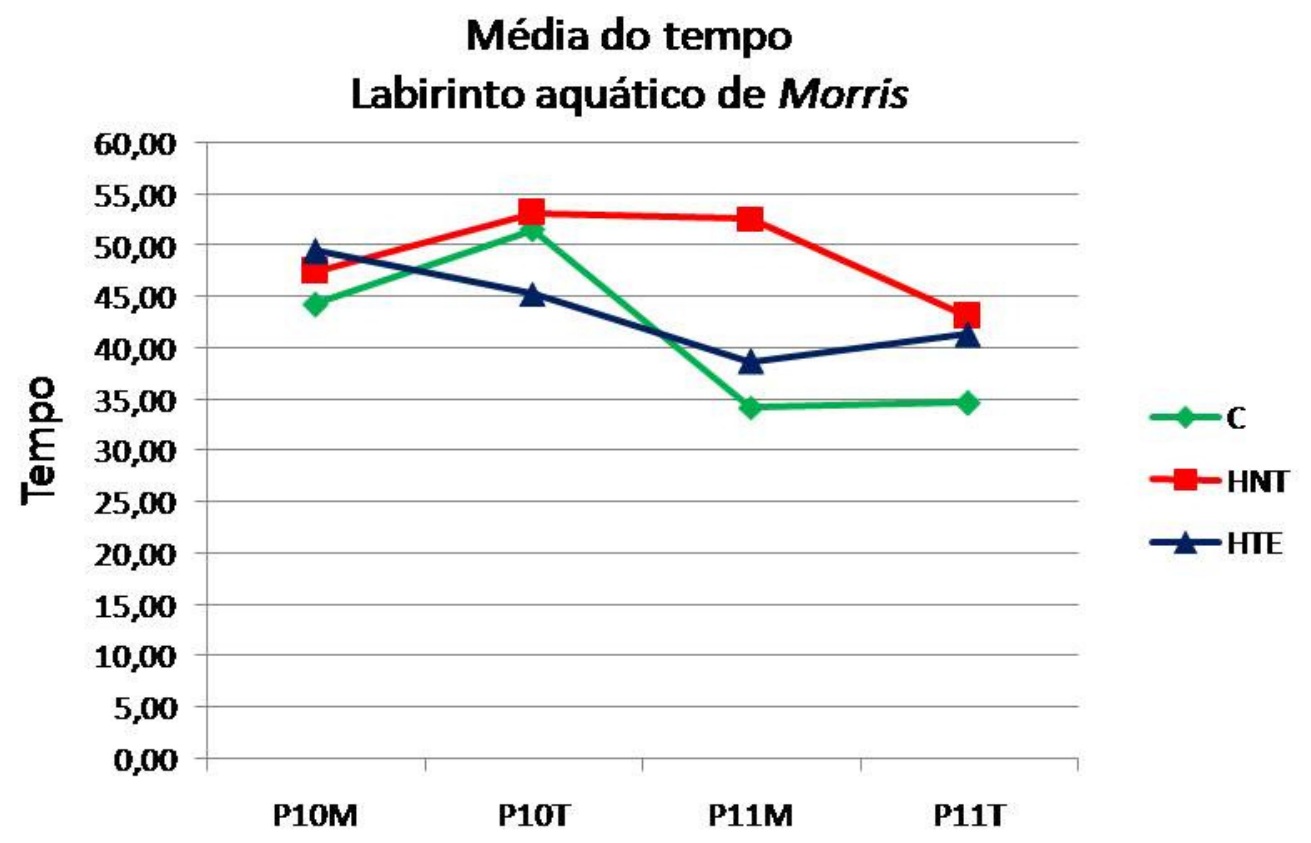

Figura 7: Gráficos representativos do desempenho no teste de memória (Labirinto Aquático de Morris), Grupos: C: controle, HNT: hidrocefálico sem tratamento e HTE: hidrocefálico tratado com edaravone mostrando que os animais do grupo HTE apresentaram melhor desempenho (chegavam à plataforma em tempo mais curto), quando comparados com os animais hidrocefálicos sem tratamento (HNT).

\subsection{Avaliação por ressonância magnética}

\subsubsection{Razão ventricular}

Através da Ressonância Magnética do encéfalo, foi quantificada a razão ventricular, calculada a partir da divisão (ou razão) entre a área do ventrículo lateral no corte coronal médio e a área total do encéfalo no mesmo corte. 
A média da razão ventricular dos animais dos grupos hidrocefálicos era semelhante, sem diferença entre eles, e ambos apresentaram média maior que os animais do grupo controle com diferença estatística significante ( $p<0.01),(C: x=0,0031 \pm 0,0019$; HTE: $\mathrm{x}=0,4432 \pm 0.0332 ; \mathrm{HNT}: \mathrm{x}=0,5450 \pm 0,0581$ ) (figura 8).

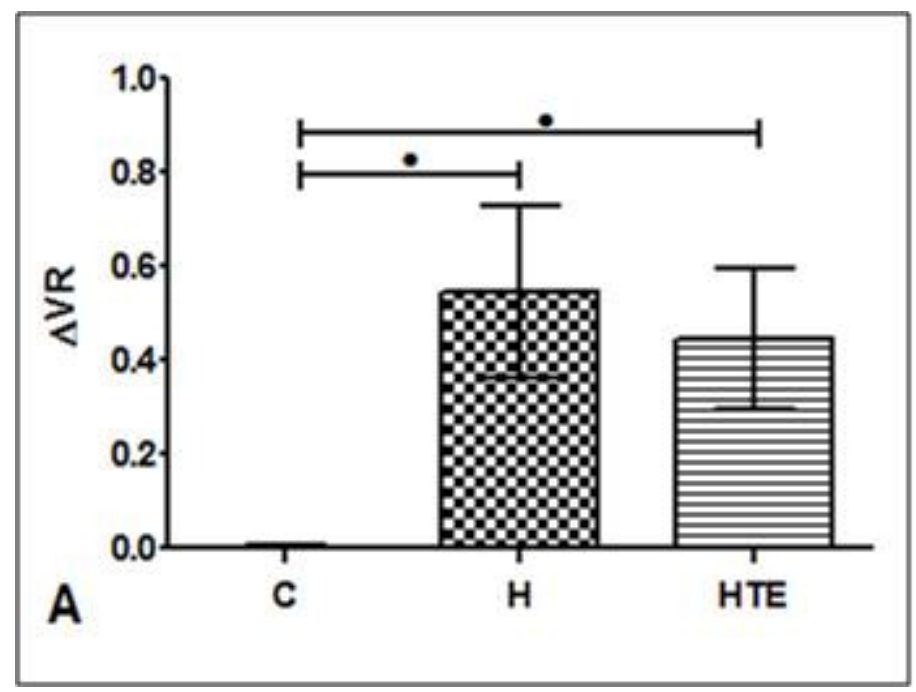

Figura 8 - Gráfico representativo da comparação das medidas de razão ventricular (RV), nos grupos estudados. Grupos: C: controle, H: hidrocefálico sem tratamento e HTE: hidrocefálico tratado com edaravone. Os animais do grupo HNT/HTE, apresentaram RV semelhante entre si. Na comparação dos grupos hidrocefálicos com o grupo C, as médias da RV de ambos os grupos hidrocefálicos eram maiores que a média do grupo controle $(p<0,01)$.

\subsubsection{Transferência de magnetização}

No estudo da transferência de magnetização, nas regiões demarcadas (região dorsal do ventrículo lateral $\mathrm{C}: \mathrm{x}=28,72 \pm 2,21$; HTE: $\mathrm{x}=33,03 \pm 2,02 ; \mathrm{HNT}: \mathrm{x}=26,7 \pm 2,48 \mathrm{e}$ região ventral ao ventrículo lateral C: $\mathrm{x}=44,14 \pm 8,28$; HTE: $\mathrm{x}=35,50 \pm 1,29$; HNT: $\mathrm{x}=38,97 \pm$ 5,96), não foram observadas diferenças estatística significativas entre os grupos pesquisados, Porém na análise no encéfalo total os animais do grupo controle apresentavam uma média do número de transferência de magnetização maior em relação aos animais hidrocefálicos $(\mathrm{p}<$ 0,05) $(\mathrm{C}: \mathrm{x}=38,42 \pm 4,26$; HTE: $\mathrm{x}=30,27 \pm 0,97$; HNT: $\mathrm{x}=32,41 \pm 1,87)$ (figura 9). 

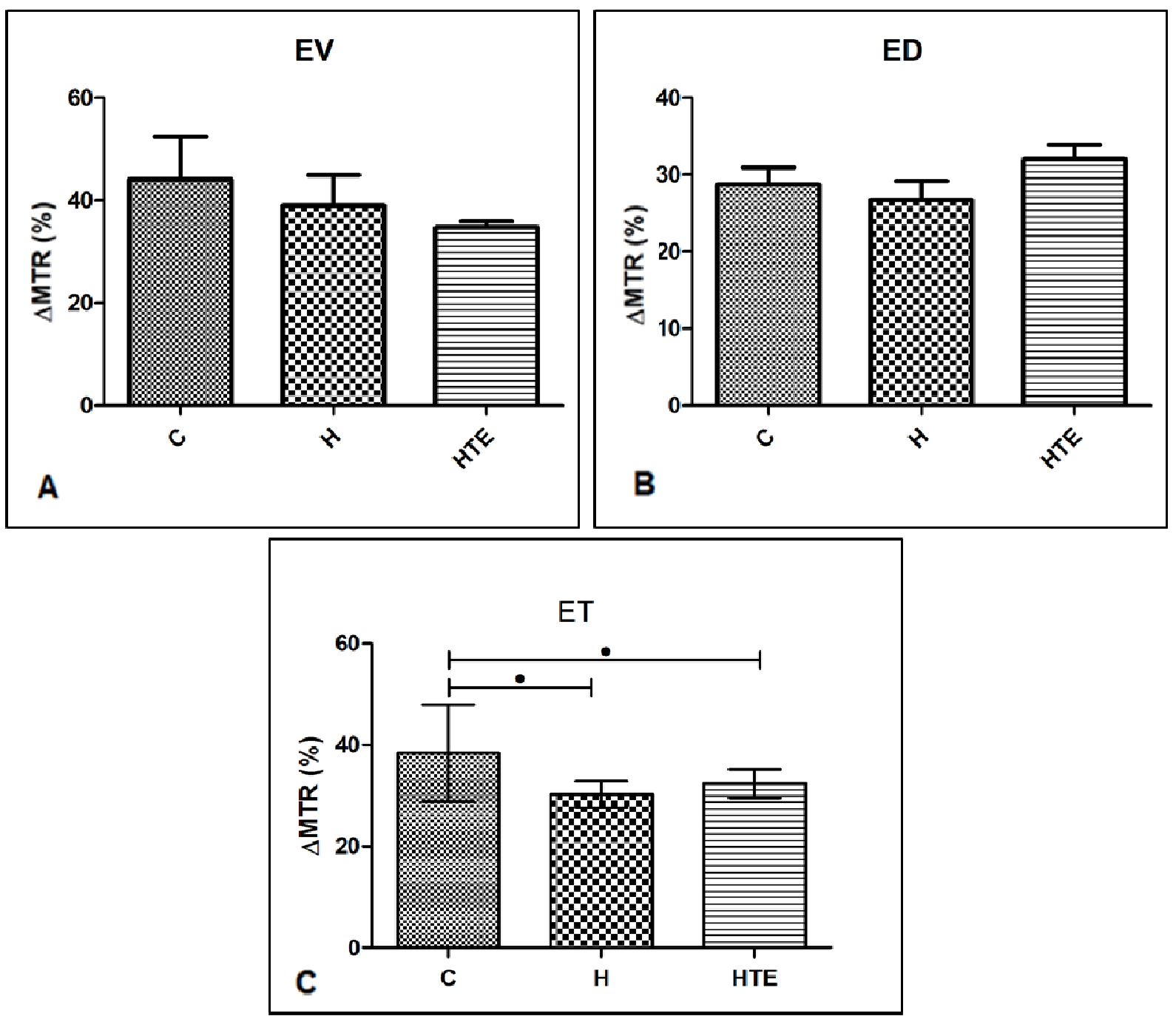

Figura 9 - Gráfico representativo da transferência de magnetização, A: região ventral ao ventrículo lateral, B: região dorsal ao ventrículo lateral, e C: encéfalo total. Grupos: C: controle, H: hidrocefálico sem tratamento e HTE: hidrocefálico tratado com edaravone. Não houve diferença nos valores obtidos no encéfalo total e nas áreas dorsais e ventrais ao ventrículo lateral, entre os grupos estudados. $\mathrm{Na}$ análise do encéfalo total os animais controles apresentavam uma média de transferência de magnetização maior quando comparados com os animais dos grupos hidrocefálicos. 


\subsection{Avaliações histoquímica}

\subsubsection{Coloração com hematoxilina e eosina}

As alterações analisadas nos encéfalos de todos os grupos foram encontradas especialmente, nas quatro regiões demarcadas (corpo caloso, matriz germinativa, cápsula externa, córtex cerebral). Os cortes com essa coloração nos animais controles mostraram que o corpo caloso apresentava-se íntegro e a camada ependimária que recobria os ventrículos laterais era contínua, com epitélio cúbico simples e células ependimárias com núcleo centralizado. $\mathrm{Na}$ análise da citoarquitetura geral pela coloração por hematoxilina e eosina, os animais hidrocefálicos apresentaram o ventrículo lateral maior, com comprometimento do epêndima, e suas células achatadas, com pontos de rotura, sendo que o comprometimento era maior, quanto maior, era a dilatação ventricular. O corpo caloso apresentava-se comprimido e estirado com sinais de edema, caracterizados como rasgões, ou seja, áreas mais claras. Nos casos de hidrocefalia máxima, o corpo caloso na linha mediana aparece completamente destruído. O córtex cerebral dorsal, e cápsula externa apesar de comprimido e estirado, manteve sua laminação preservada (figura 10). 


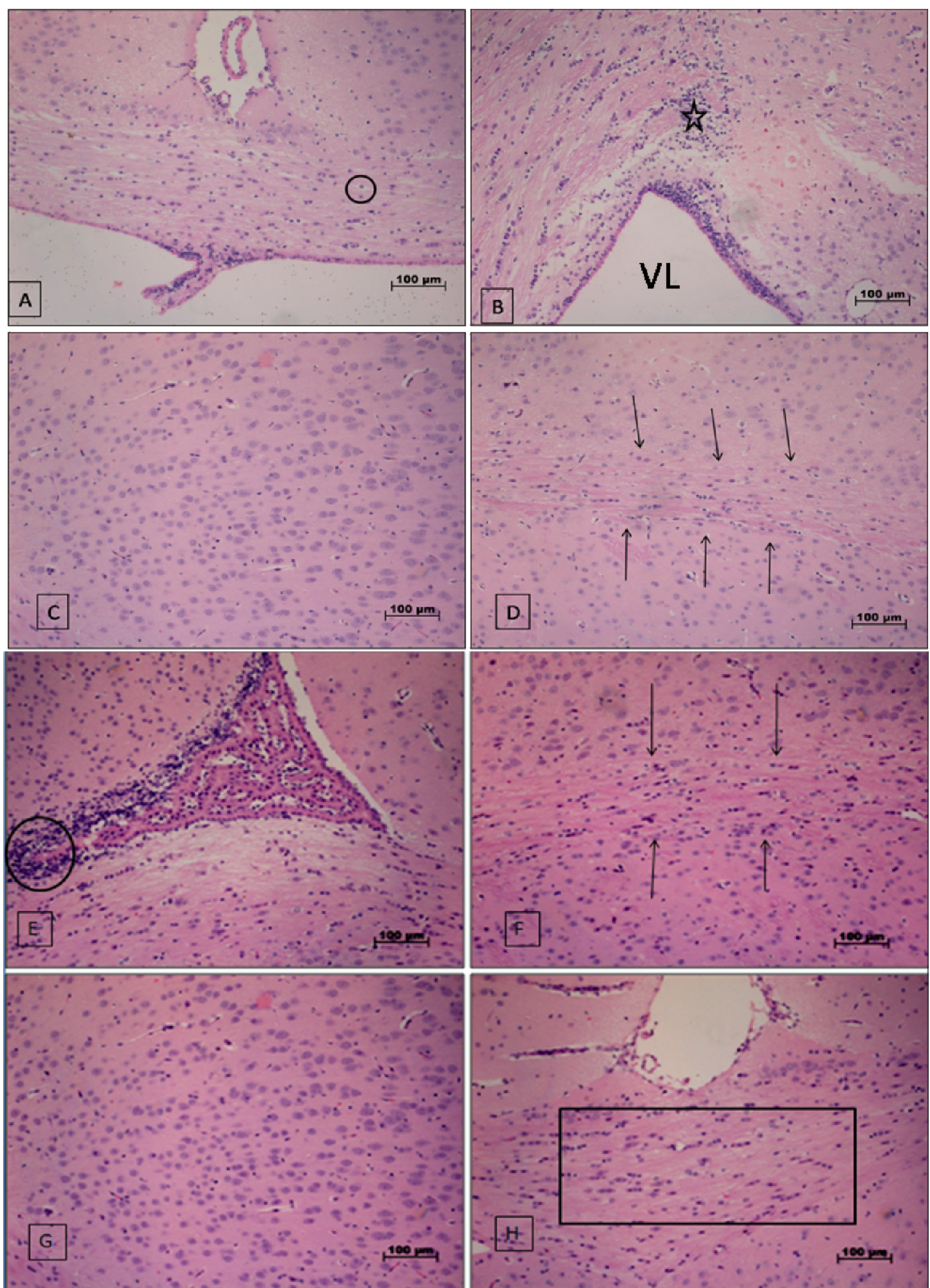

Figura 10 - Fotomicrografias do encéfalo de rato hidrocefálico (A) corpo caloso, (B) matriz germinativa, (C) córtex cerebral, (D) cápsula externa (entre as setas), fotomiografias do encéfalo de rato controle (E) matriz germinativa $(\mathrm{F})$ cápsula externa (entre as setas), $(\mathrm{G})$ córtex cerebral e $(\mathrm{H})$ corpo caloso (quadrado) (VL) ventrículo lateral. Pode se observar nos encéfalos dos ratos hidrocefálicos, edema leve (círculo), região da matriz germinativa (estrela) com ângulo do ventrículo dilatado. Nos encéfalos dos animais controles a laminação manteve preservada. Coloração- hematoxilina e eosina. Objetiva de 40X. Barra$100 \mu \mathrm{m}$. 


\subsubsection{Coloração com solocromo-cianina}

$\mathrm{Na}$ análise pela coloração solocromo-cianina, foi avaliado o grau de mielinização da substância branca periventricular, que é corada em azul, através de uma análise de confrontação visual do corpo caloso dos ratos. Foi aplicado um score de 0 a 2 para classificação da intensidade de coloração, sendo 0: tonalidade fraca em azul, 1: tonalidade média em azul e 2: tonalidade forte em azul (Figura 12). Os animais do grupo controle apresentaram-se com uma tonalidade mais intensa em azul, quando comparados com os grupos hidrocefálicos (HTE/HNT), indicando uma progressiva mielinização do corpo caloso, com diferença estatística $(\mathrm{p}<0,05)$. A comparação dos animais hidrocefálicos (HTE e HNT) não exibiu diferença estatística na média do score, porém a tonalidade do azul no corpo caloso dos animais sem tratamento mostrou ser mais leve em relação ao grupo tratado com Edaravone. (Figura 11).

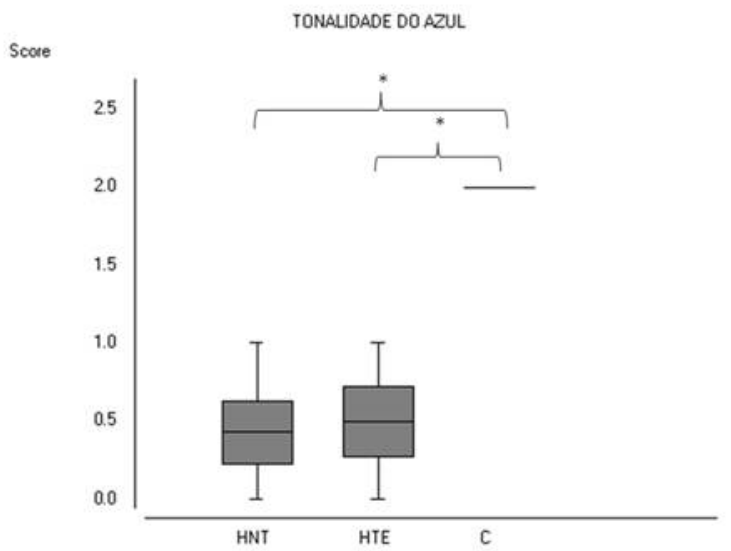

Figura 11 -Comparação da tonalidade em azul no corpo caloso, tabulada através de um score de 0 a 2. Grupos: C: controle, HNT: hidrocefálico sem tratamento e HTE: hidrocefálico tratado com edaravone Houve diferença estatística entre os grupos hidrocefálicos comparados com o grupo controle, mostrando que os animais do grupo controle apresentavam uma progressiva mielinização em relação aos animais hidrocefálicos $(* \mathrm{p}<0,05)$. 

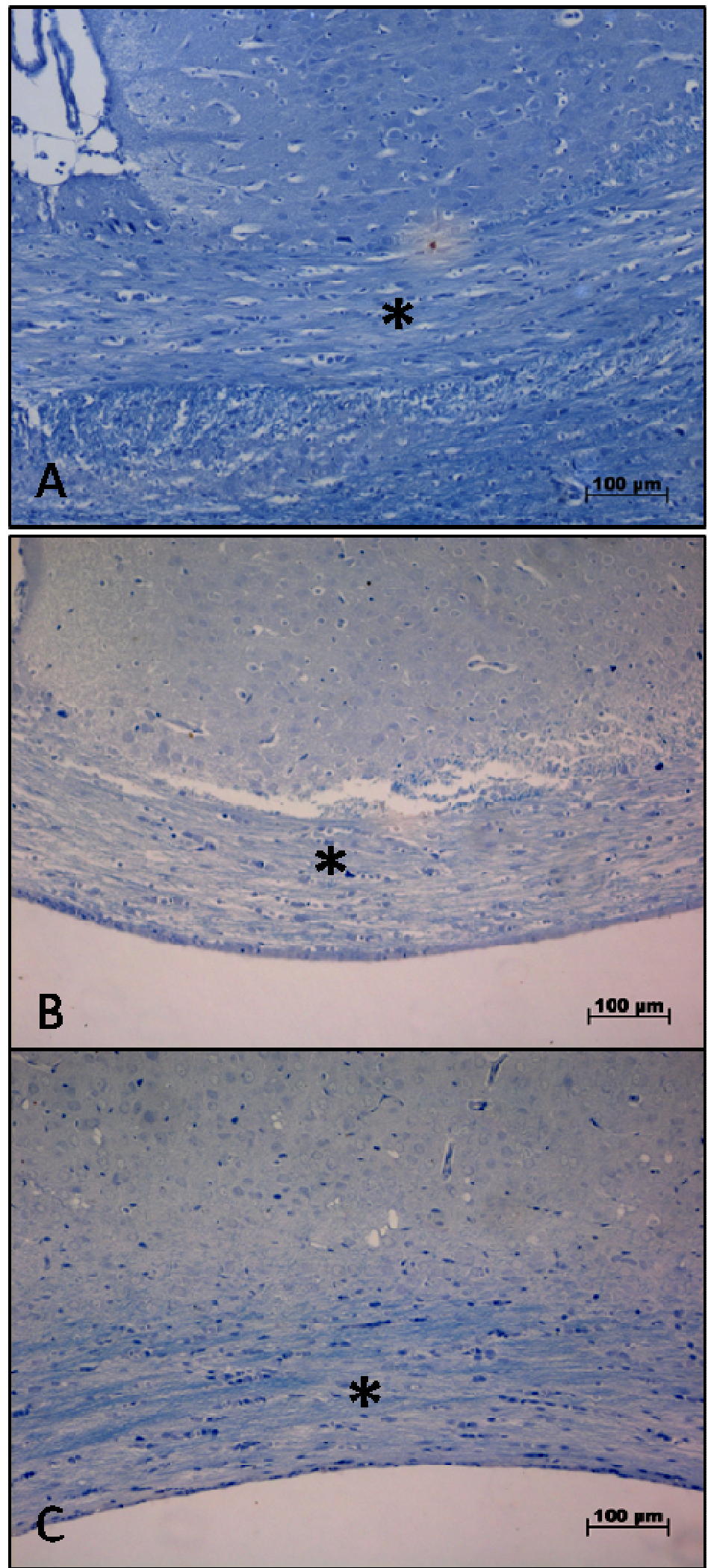

Figura 12 - Fotomicrografias do corpo caloso de ratos (21 dias de vida)

- (A) Controle (B) Hidrocefálico não tratado (C) Hidrocefálico tratado com Edaravone, mostrando maior espessura do corpo caloso nos animais controles em relação aos grupos hidrocefálicos. Coloração: solocromo-cianina. Objetiva de 10X. Exposição de luz: 90.0 ms. Barra - 100 $\mu \mathrm{m}(*)$ corpo caloso. 
Para associar a gravidade da ventriculomegalia ao nível de lesão foram realizadas medições da espessura do corpo caloso sendo a estrutura mais próxima dos ventrículos laterais e mais suscetível à lesão e. Na comparação entre os grupos (HNT, HTE e C) observou-se maior espessura do corpo caloso nos animais controles, quando comparados com ambos os grupos hidrocefálicos $(\mathrm{p}<0,01)$. Já na comparação entre os grupos HTE e HNT, não foi encontrada diferença $(C: x=214.72 \pm 14.65$; HTE: $x=100.56 \pm 5.68$; HNT: $x=97.91 \pm$ 2.67) (figura 13). Foi realizado um coeficiente de correlação linear de Spearman entre a espessura do corpo caloso e razão ventricular, mostrando que existe uma correlação entre esses dados com diferença significante $(\mathrm{p}<0.0001)$ (figura 14).

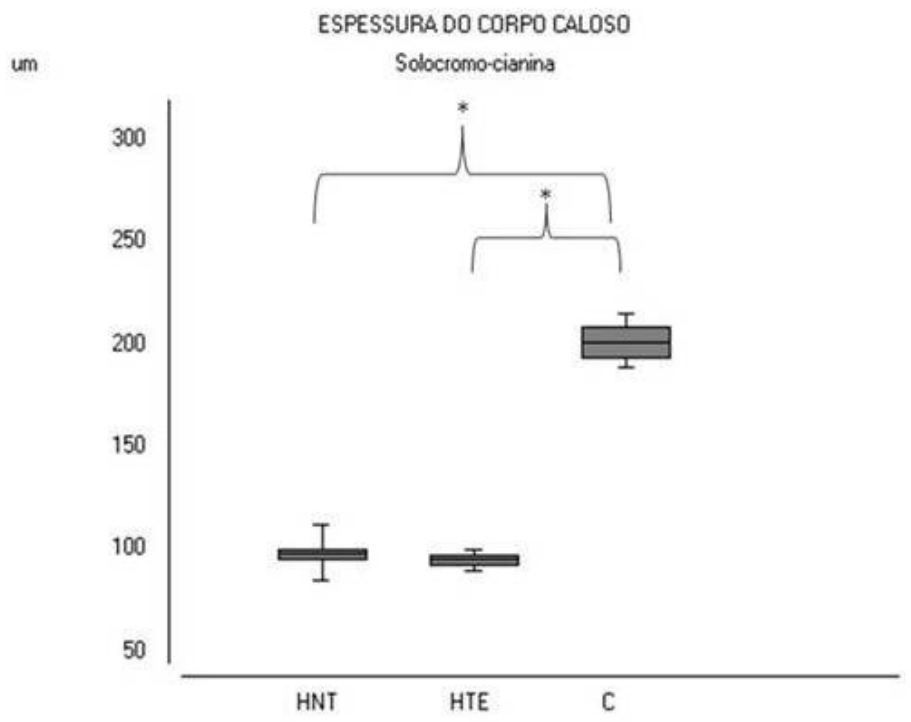

Figura 13 - Comparação das medidas de espessura de corpo caloso, demonstrando diferença entre o grupo controle e os grupos hidrocefálicos $(* \mathrm{p}<0,01)$. Grupos: C: controle, HNT: hidrocefálico sem tratamento e HTE: hidrocefálico tratado com edaravone Não houve diferença entre o grupo hidrocefálico não tratado e o tratado com Edaravone. 


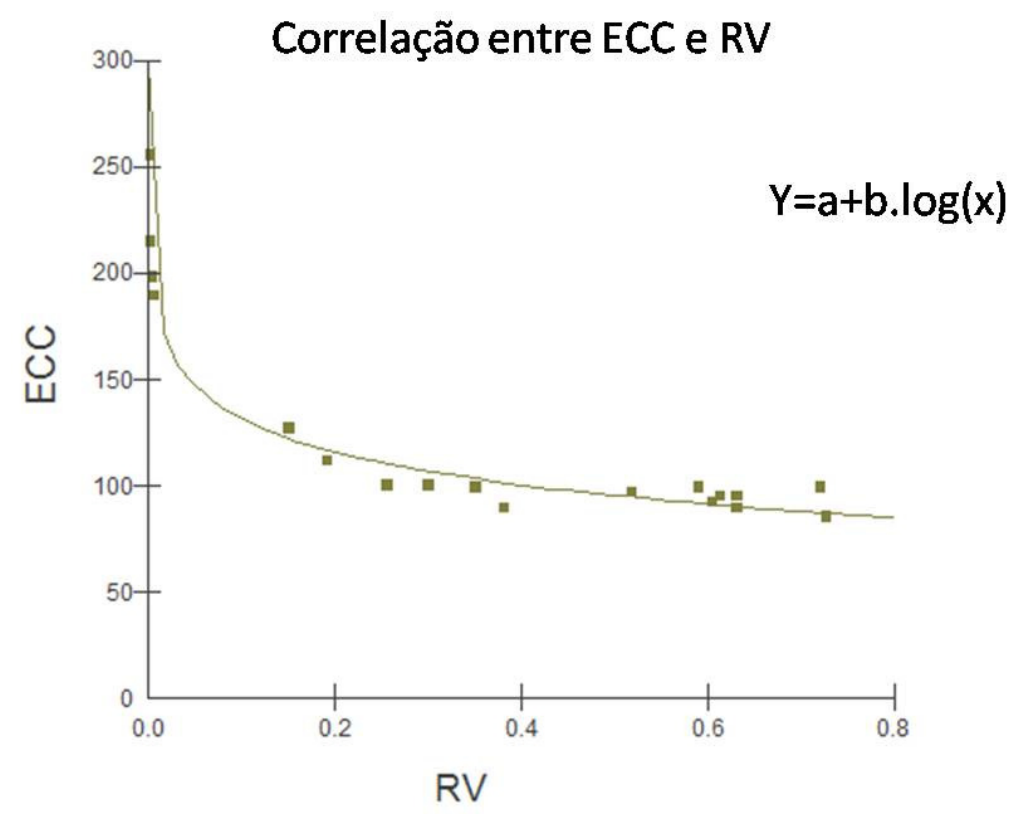

Figura 14 - Correlação linear de Spearman ( $\mathrm{p}<0.0001)$. Mostrando que há uma correlação significante entre a espessura do corpo caloso e razão ventricular.

\subsection{Avaliações imunoistoquímicas}

\subsubsection{Estudo imunoistoquímico do GFAP}

Os astrócitos marcados no corpo caloso e na matriz germinativa dos animais do grupo controle, não exibiam sinais de hipertrofia, com marcação tênue e prolongamentos pouco visíveis. Por outro lado, os animais do grupo HNT, exibiam astrócitos intensamente marcados, com prolongamentos mais grosseiros, enquanto que os animais tratados com Edaravone também apresentavam astrócitos reativos, mas com prolongamentos mais finos e delicados (figura 15). Observou-se que houve diferença estatística na comparação entre o grupo $\mathrm{C}$ com os grupos HNT e HTE, com uma maior atividade astrocitária nos animais hidrocefálicos $(\mathrm{p}<0,05)$, para as duas regiões avaliadas.

As médias de astrócitos reativos, encontradas no corpo caloso dos diferentes grupos experimentais foram: $\mathrm{C}: \mathrm{x}=166,67 \pm 72,65 ;$ HNT: $\mathrm{x}=1565,0 \pm 412,04$; HTE: $\mathrm{x}=2283,33 \pm 1244,51$ e as médias de astrócitos reativos, encontradas na matriz germinativa são (C: $x=283,32 \pm 175,89$; HNT: $x=310,83 \pm 169,55$; HTE: $x=380,25 \pm 142,55$ ), (figura 16). 

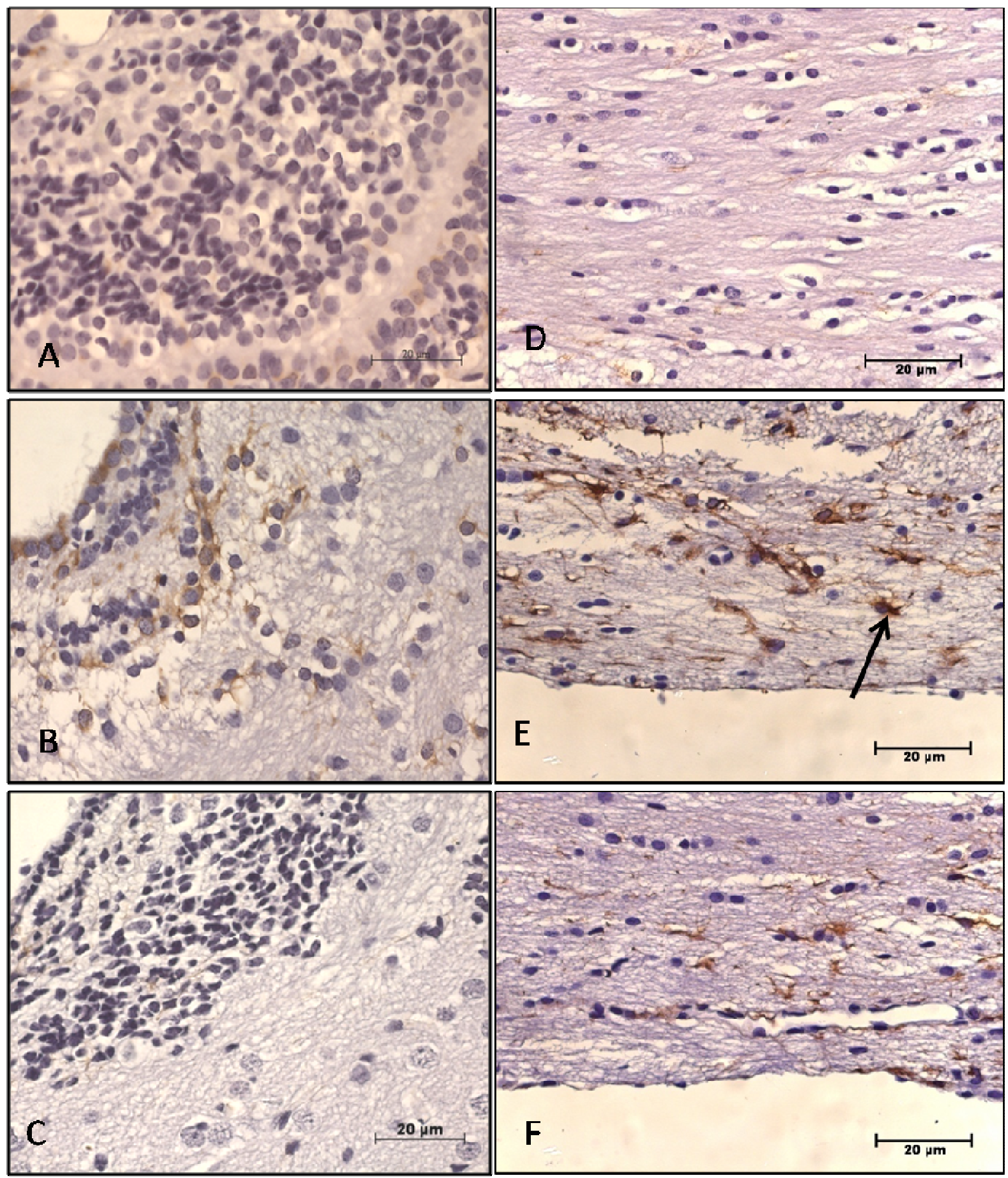

Figura 15 - Fotomicrografias da matriz germinativa com imunomarcação para o GFAP de ratos (21 dias de vida) (A) Controle (B) Hidrocefálico não tratado (C) Hidrocefálico tratado com Edaravone. Observa-se que o grupo hidrocefálico não tratado apresenta astrócitos intensamente marcados, quando comparados com os outros grupos experimentais. Fotomicrografias do corpo caloso com imunomarcação para o GFAP de ratos (21 dias de vida), (D) Controle. (E) Hidrocefálico não tratado. (F) Hidrocefálico tratado com Edaravone. Observa-se que o grupo hidrocefálico não tratado apresenta astrócitos intensamente marcados, quando comparados com os outros grupos experimentais. Objetiva de 40X (imersão). Barra - $20 \mu \mathrm{m}$. 


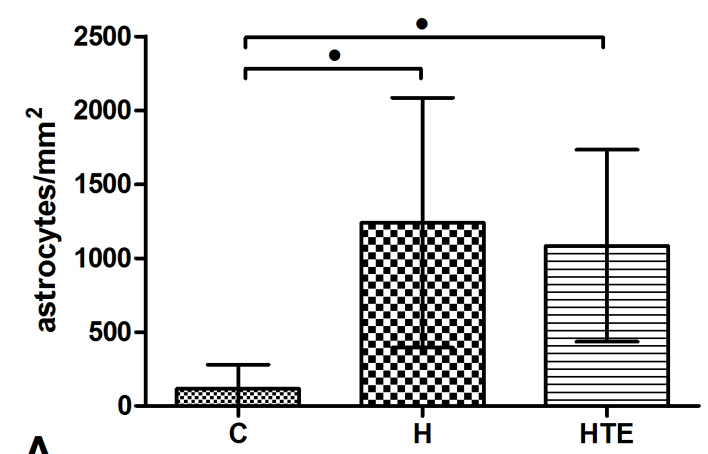

A

H

HTE

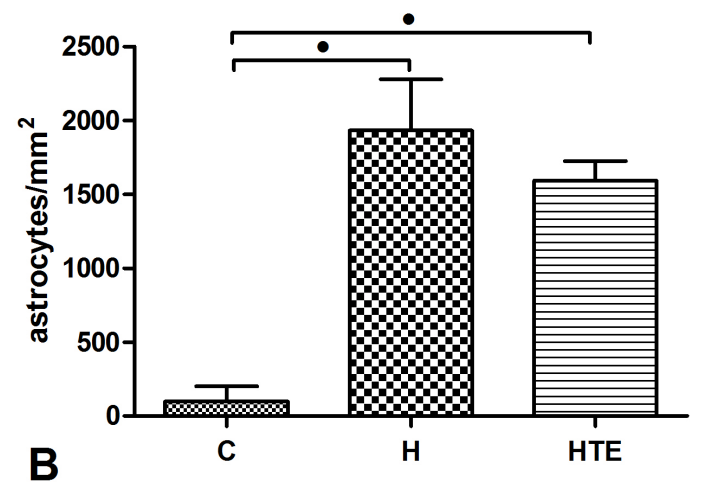

Figura 16 - Gráfico representativo da densidade de astrócitos imunomarcados pelo GFAP. Grupos: C: controle, H: hidrocefálico sem tratamento e HTE: hidrocefálico tratado com edaravone A. na região do corpo caloso e B. matriz germinativa nos diferentes grupos experimentais. Demonstração dos animais pertencentes ao grupo não tratado com uma maior reação astrocitária quando comparado com grupo controle $* \mathrm{p}<0,05$.

Na classificação através de um score 0 a 2 de astrogliose, foram observadas todas a fotos das regiões estudadas e tabuladas em 0: ausência de astrócitos reativos, 1: astrócitos reativos com prolongamentos finos e delicados e 2: astrócitos reativos com prolongamentos grossos. Nas áreas observadas tanto no corpo caloso quanto na matriz germinativa, os animais tratados com Edaravone mostraram um score menor quando comparados com os animais não tratados, porém essa diferença não foi significativa. $\mathrm{Na}$ comparação entre os grupos HTE/HNT com o grupo $\mathrm{C}$, os animais do grupo controle obtiveram uma média menor em relação aos dois grupos hidrocefálicos $(\mathrm{p}<0,01)$ (figura 17). 
Categorização por score/GFAP

Corpo caloso

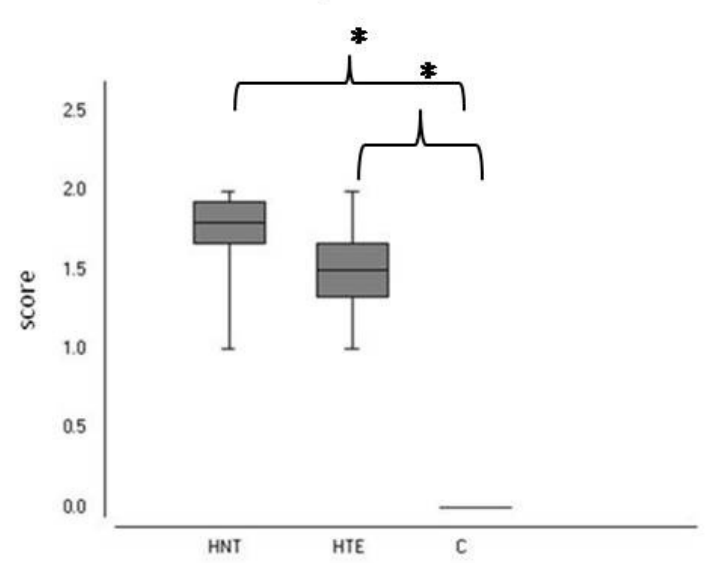

Categorização por score/GFAP

Matriz Germinativa

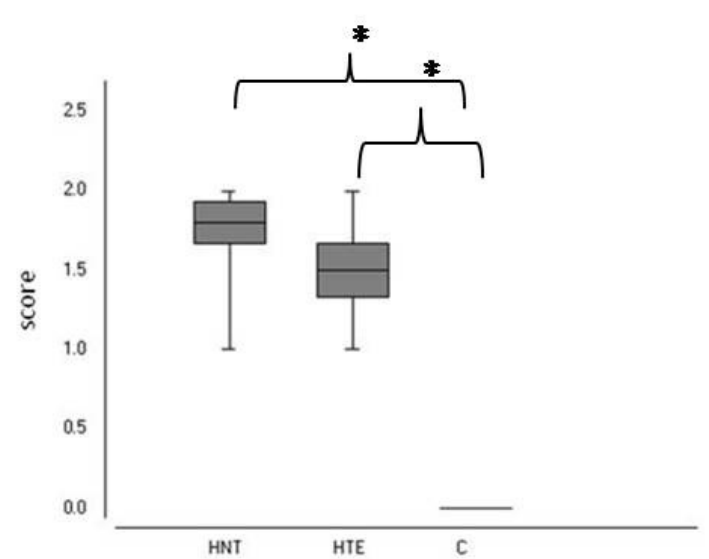

Figura 17 - Gráfico representativo da densidade dos astrócitos imunomarcados por GFAP categorizado por um score. Grupos: C: controle, HNT: hidrocefálico sem tratamento e HTE: hidrocefálico tratado com edaravone Os animais do grupo HNT, mostraram-se com uma marcação mais intensa e proliferativa no corpo caloso e na matriz germinativa, quando comparados com os outros grupos experimentais. Na comparação entre os grupos HTE/HNT com o grupo $\mathrm{C}$, houve diferença estatística significativa, mostrando que os animais do grupo controle obtiveram uma média menor em relação aos grupos hidrocefálicos.

\subsubsection{Estudo imunoistoquímico do Ki-67}

$\mathrm{Na}$ análise imunoistoquimica com anticorpo Ki-67, foram contabilizadas as células em divisão mitótica imunomarcadas na região da matriz germinativa, localizada no ângulo externo dos ventrículos laterais do cérebro.

A comparação das médias entre os grupos experimentais referentes à densidade de células em divisão mitótica. $\mathrm{Na}$ análise comparativa dos dados dos grupos hidrocefálicos (HNT/HTE) não mostrou diferença significativa. No entanto, a comparação dos grupos hidrocefálicos (HNT/HTE) com o grupo C há diferença estatística significativa, esses animais controles exibiram densidade celular na região da matriz germinativa significativamente maior que os demais grupos $(\mathrm{p}<0,01)$ (figura 18).

Na figura 19, é possível observar a maior densidade de células marcadas na matriz germinativa de um rato controle. Na comparação visual entre os grupos hidrocefálicos sem tratamento e hidrocefálicos tratados com Edaravone, o padrão de imunomarcação era semelhante. 


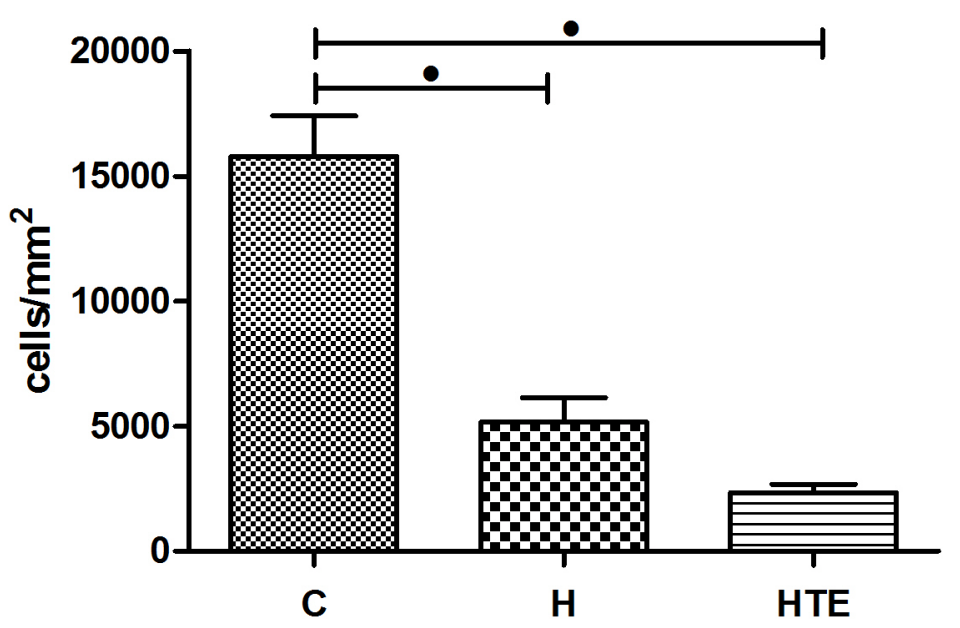

Figura 18 -Gráfico representativo da densidade de células em divisão mitótica imunomarcadas pelo anticorpo Ki-67. Grupos: C: controle, $\mathrm{H}$ : hidrocefálico sem tratamento e HTE: hidrocefálico tratado com edaravone na região da matriz germinativa nos diferentes grupos experimentais. Na comparação dos grupos hidrocefálicos HNT/HTE com o grupo C, mostrou-se que os animais do grupo controles exibiram densidade celular significativamente maior que os demais grupos $(\mathrm{p}<0,01)$. 


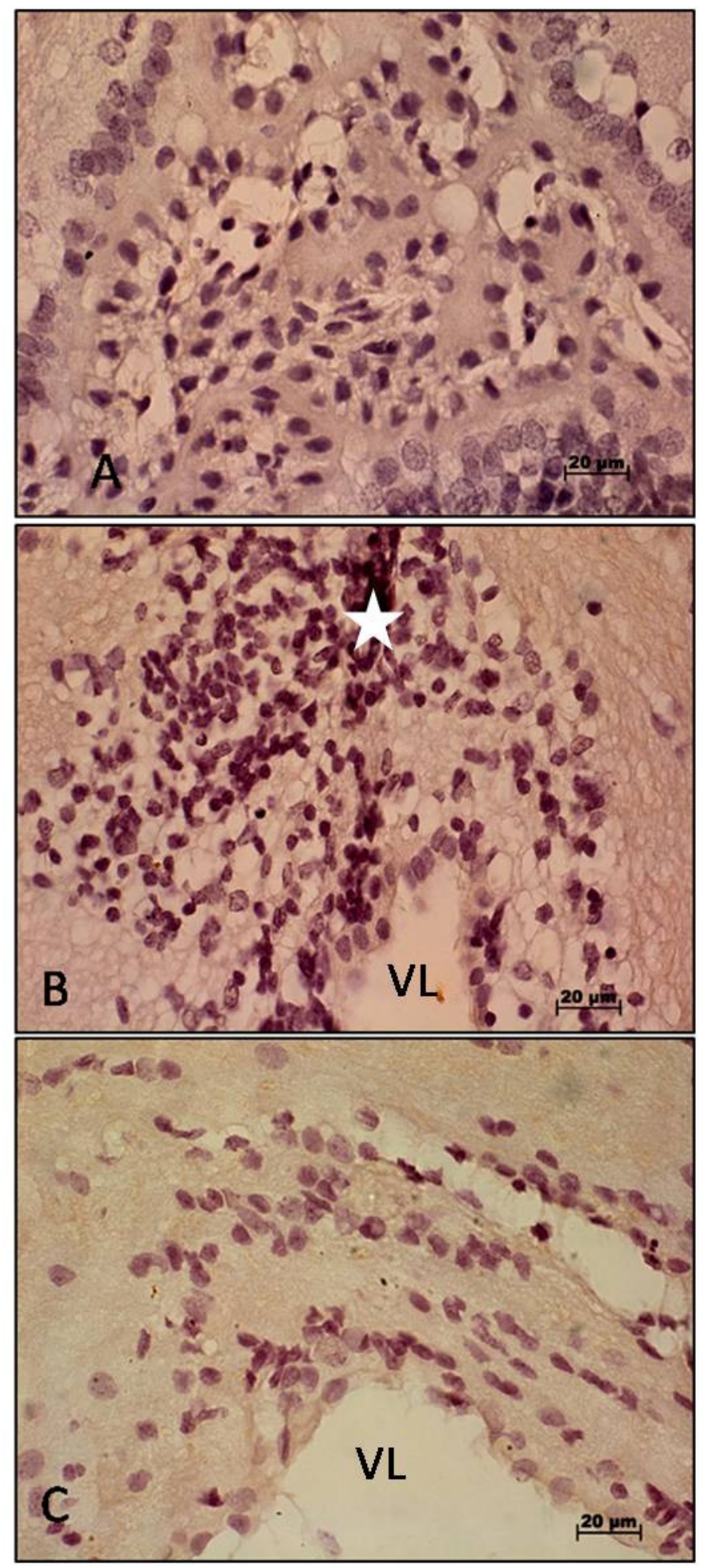

Figura 19 -Fotomicrografias da matriz germinativa com imunomarcação para o Ki-67 de ratos (21 dias de vida) (A) Controle (B) Hidrocefálico não tratado (C) Hidrocefálico tratado com Edaravone.. Observa-se que o grupo $\mathrm{C}$ apresenta maior proliferação celular, quando comparados com os outros grupos experimentais, proliferação celular (estrela), ventrículo lateral (VL). Objetiva de 40X (imersão). Barra - $20 \mu \mathrm{m}$. 


\subsubsection{Estudo imunoistoquímico por caspase-3}

$\mathrm{Na}$ análise pela marcação de caspase-3 foram estudadas as regiões do corpo caloso e córtex dorsal e realizada uma varredura nestas áreas e contabilizadas as células em processos de apoptose. Na região do corpo caloso não houve diferença estatística na comparação dos grupos experimentais, porém, os animais dos grupos hidrocefálicos apresentaram-se com um número da média maior de células em apoptose, quando comparadas ao grupo controle, $(\mathrm{C}: \mathrm{x}=0,22 \pm 0,11$; HTE: $\mathrm{x}=1,6 \pm 1,24$; HNT: $\mathrm{x}=2,67 \pm 1,65)$.

Já no córtex cerebral dorsal, observamos diferença estatística $(\mathrm{p}<0.01)(\mathrm{C}$ : $\mathrm{x}=0,22 \pm 0,11$; HTE: $\mathrm{x}=1,23 \pm 0,32$; HNT: $\mathrm{x}=1,31 \pm 0,39$ ), entre o grupo controle e o grupo HNT (figura 20).
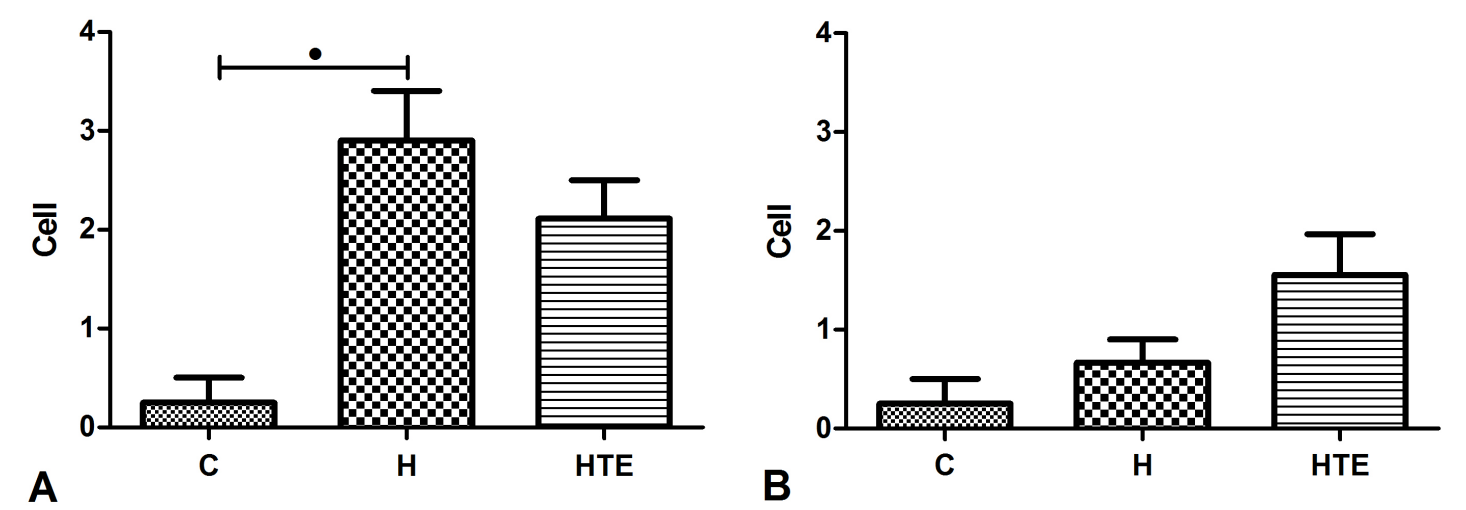

Figura 20 - Gráfico representativo referente à imunomarcação pelo anticorpo caspase-3. Grupos: C: controle, H: hidrocefálico sem tratamento e HTE: hidrocefálico tratado com edaravone no (A) córtex cerebral dorsal e (B) corpo caloso, nos diferentes grupos experimentais $\left({ }^{*} \mathrm{p}<0.01\right)$, demonstrando que na região do córtex dorsal, os animais do grupo HTE apresentaram uma quantidade menor de células em apoptose em relação ao grupo HNT.

\subsubsection{Estudo da reação microglial por lectina}

$\mathrm{Na}$ análise das lâminas para estudo da reação das células da microglia, não foram encontradas diferenças estatísticas na comparação das médias da contagem de células marcadas da região do córtex dorsal (Córtex cerebral: $C$ : $x=0,09 \pm 0,10$; HTE: $x=0,91 \pm 0,68$; HNT: $\mathrm{x}=0,95 \pm 1,37$ ). No corpo caloso, os animais do grupo HNT apresentavam uma média 
maior quando comparados com os do grupo C. (Corpo caloso: $\mathrm{C}$ : $\mathrm{x}=0,22 \pm 0,33$; HTE: $\mathrm{x}=1,0 \pm 0,61$; HNT: $\mathrm{x}=1,61 \pm 1,13$ ) (figura 21).

Lectina

Corpo caloso

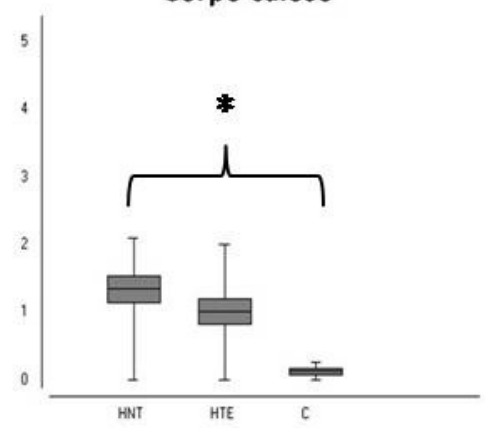

A
Lectina

Córtex dorsal

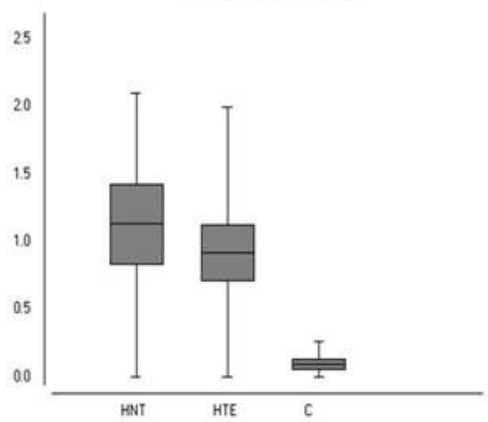

B

Figura 21 - Gráfico representativo referente à reação microglial. Grupos: C: controle, HNT: hidrocefálico sem tratamento e HTE: hidrocefálico tratado com edaravone (A) corpo caloso e (B) córtex dorsal nos diferentes grupos experimentais. (A) Mostra que os animais do grupo HNT apresentaram uma reação microglial maior do que os animais do grupo $\mathrm{C}$, com diferença significativa $(\mathrm{p}=<0.01)$ na comparação entre os grupos hidrocefálicos não houve diferenças estatísticas.

\subsection{Estudo bioquímico}

\subsubsection{Avaliação da atividade da glutationa peroxidase}

Na dosagem da Glutationa Peroxidase presente no tecido encefálico foi usado o "Glutathione Peroxidase Assay Kit (GPx)". Mediante comparação entre os três grupos experimentais não foram encontradas diferenças estatísticas significantes das médias (C: $\mathrm{x}=0,9 \pm 1,02$; HTE: $\mathrm{x}=1,14 \pm 1,24$; HNT: $\mathrm{x}=2,29 \pm 1,87$ ) (Figura 22). 


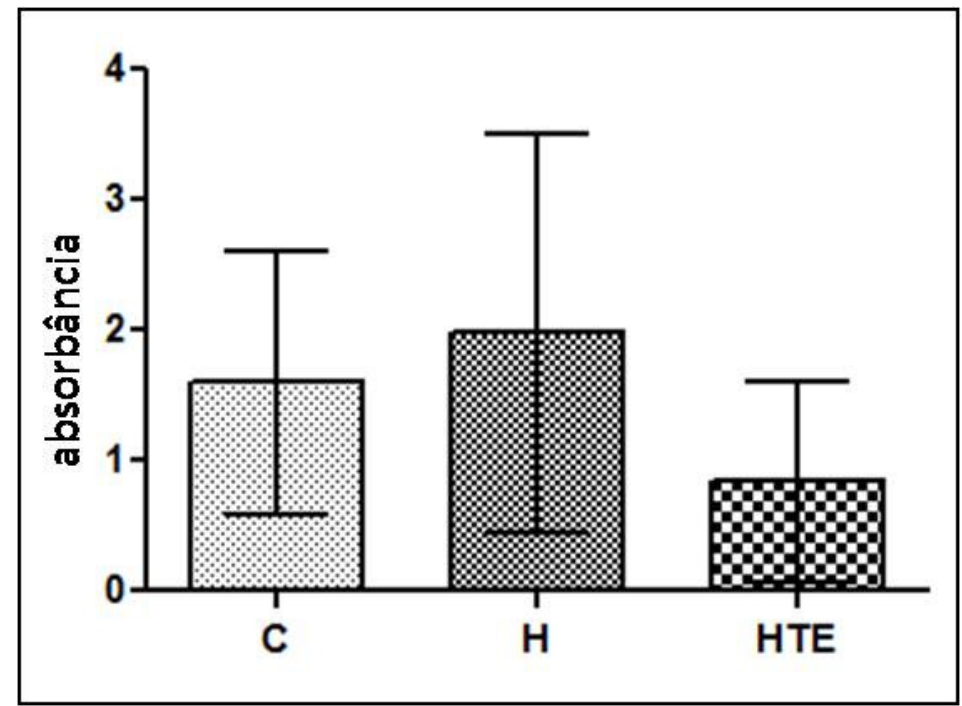

Figura 22 - Gráfico representativo referente aos valores de glutationa presentes no tecido. Grupos: C: controle, H: hidrocefálico sem tratamento e HTE: hidrocefálico tratado com edaravone. Os animais tratados com Edaravone mostraram um nível menor de glutationa, quando comparados com os outros grupos, porém sem diferenças estatísticas.

\subsubsection{Avaliação dos antioxidantes totais presentes no plasma}

A comparação das médias entre os grupos experimentais mostrou diferença estatística significativa entre os grupos hidrocefálicos em relação ao grupo C, tanto de HNT quanto de HTE $(\mathrm{p}<0,05)$. Esses animais do grupo controle exibiram quantidade de antioxidantes totais significativamente maiores em relação aos demais grupos. No entanto, a comparação dos grupos hidrocefálicos, HNT e HTE, não apresentavam diferença significante (C: $x=0,2 \pm 0,04$; HTE: $x=0,08 \pm 0,04$; HNT: $x=0,10 \pm 0,07$ ) (figura 23). 


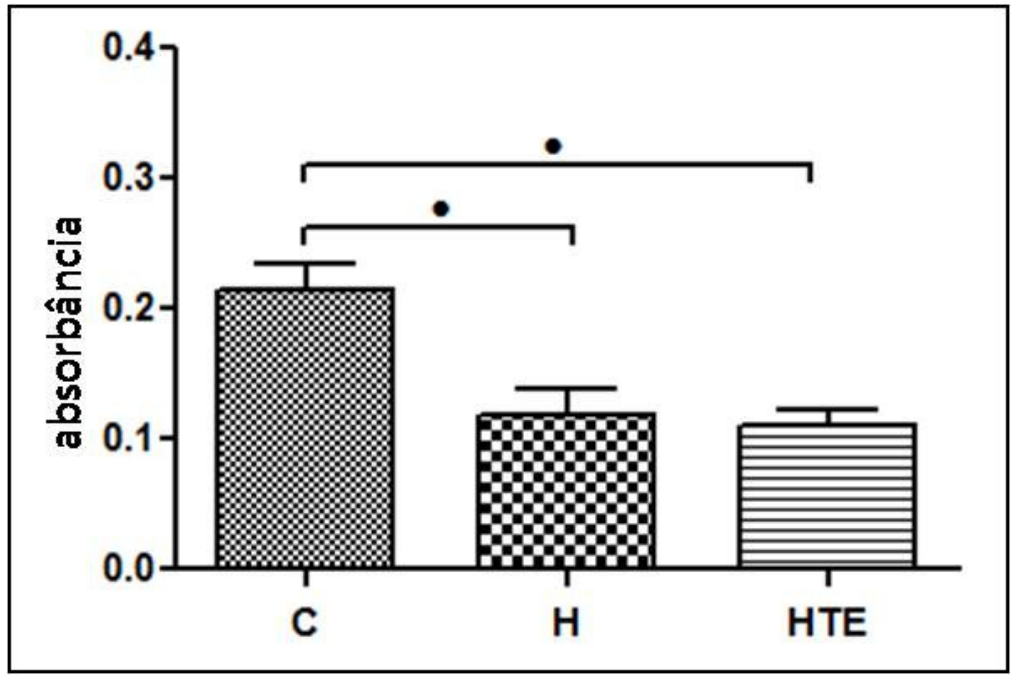

Figura 23 - Gráfico representativo referente aos valores de antioxidantes totais presentes no plasma. Grupos: C: controle, H: hidrocefálico sem tratamento e HTE: hidrocefálico tratado com edaravone Os animais do grupo $\mathrm{C}$ mostraram uma média maior referente ao nível de antioxidantes, quando comparados com os outros grupos com diferenças estáticas significativas $(* \mathrm{p}<0,05)$.

\subsubsection{Tbars}

A peroxidação lipídica foi avaliada através da dosagem do malondialdeído (MDA) através do método TBARS. Não foram encontradas diferenças estatísticas significantes entre os 3 grupos analisados $(C: x=3,5 \pm 3,32$; HTE: $x=6,27 \pm 5,27$; HNT: $\mathrm{x}=6,14 \pm 3,52$ ) (figura 24). 


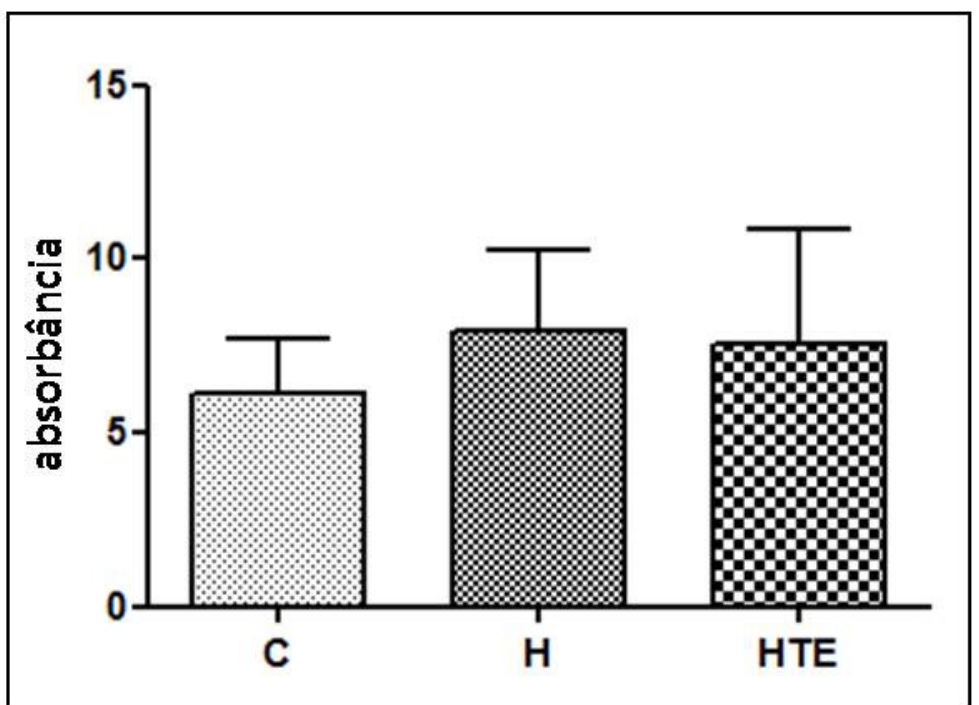

Figura 24 - Gráfico representativo referente aos valores de malondeido, presentes no tecido. Grupos: C: controle, H: hidrocefálico sem tratamento e HTE: hidrocefálico tratado com edaravone Os animais tratados com Edaravone mostraram um nível maior, quando comparados com os outros grupos, porém dem estatísticas. 
6. DISCUSSÃO 
A proposta do presente trabalho foi avaliar o papel da produção dos radicais livres nas lesões encefálicas encontradas na hidrocefalia experimental induzida em ratos jovens, e testar uma droga com efeito antioxidante, o Edaravone, de uso inédito no tratamento da hidrocefalia. Para avaliação foram considerados dados obtidos através da evolução do ganho diário de peso dos animais, análise comportamental com testes específicos para avaliar capacidade de aprendizagem, memória e desenvolvimento sensoriomotor, estudos histopatológicos para averiguação da citoarquitetura geral e mielinização do encéfalo, análises de imunoistoquímica para constatar o grau de astrogliose, número de células em divisão mitótica na matriz germinativa e a morte celular por apoptose, estudos bioquímicos com dosagens de antioxidantes totais no sangue e medição da peroxidação lipídica do tecido nervoso.

A avaliação do ganho ponderal fornece dados relevantes em relação à progressão da doença e nível de desidratação dos animais com hidrocefalia. Nossos resultados não mostraram diferença significante das médias de peso entre os 3 grupos experimentais estudados, porém entre o período de P6 a P8 o grupo C apresentou um ganho de peso maior quando comparado aos grupos hidrocefálicos (HNT, HTE). Na comparação entre HNT e HTE, os animais do grupo HTE obtiveram um ganho de peso menor em comparação aos animais do grupo HNT. Isso pode ser explicado pelo fato de os animais do grupo HTE, além de sofrerem o estresse da hidrocefalia, também receberam diariamente uma injeção intraperitoneal com a droga testada, o que poderia levar à inibição na procura para alimentação, por dor. A partir do P9, os animais de todos os grupos apresentaram um ganho de peso semelhante. Tal achado pode ser resultante da adaptação com o quadro patológico. Catalão e colaboradores encontraram resultados similares de variação do peso corporal na hidrocefalia induzida por caulim em ratos Wistar, isto é, na primeira metade do experimento, os animais com hidrocefalia ganhavam menos peso que os controles, mas essa diferença foi diminuindo até que, no final do experimento, os animais hidrocefálicos não tratados apresentavam ganho ponderal semelhante ao dos controles sadios (CATALAO et al., 2014).

A medição da atividade locomotora dos animais em testes de campo aberto pode ser útil para avaliar a progressão da doença e da eficácia de tratamentos instituídos. Em geral, o teste de campo aberto tem a vantagem de ser de fácil execução, não necessitando manusear o animal durante o teste, por não ser invasivo e podendo ser executado várias vezes durante o período experimental (TATEM et al., 2014). Entretanto, 
é um teste semi-quantitativo, pois é atribuído ao desempenho de cada animal um score, podendo estar incluído nesta avaliação um erro de julgamento do observador. Com o objetivo de avaliar a atividade motora e exploratória, os animais foram submetidos ao teste de campo aberto nos dias experimentais P06, P08, P10, P12 e P14. No P06, os animais dos diferentes grupos experimentais, incluindo os controles, mostraram uma dificuldade na execução da marcha, apresentando uma curvatura cifótica dorsal, marcha com desequilíbrio e base alargada. Estes sinais são considerados dentro dos padrões em ratos com essa idade, pois o encéfalo do animal não completou o seu desenvolvimento e maturação (TATEM et al., 2014). No P8 os animais do grupo tratado com Edaravone mostraram uma maior exploração na arena, um padrão de marcha menos alargado, quantidade de movimentos de luta e limpeza corporal, com diferença estatística significante quando comparados com os dos grupos HNT e C. No teste de P10 os animais do grupo $\mathrm{C}$ apresentavam um comportamento semelhante com os animais do grupo HTE, havendo diferença estatística quando comparados com os animais do grupo HNT. Já P12 e P14, os animais dos grupos HTE e C se mostravam maior exploração do ambiente, marcha normal e cuidados com a higiene, em relação aos animais do grupo HNT. Esses resultados podem indicar que os animais tratados com Edaravone melhoram sua atividade motora. No entanto, sinais de luta e limpeza corporal excessiva podem ser indicativos de que os animais estão com aumento do nível de irritabilidade, que poderia ser resultante da aplicação diária por injeção da droga testada.

$\mathrm{Na}$ realização do teste do labirinto aquático de Morris modificado, os animais dos diferentes grupos eram treinados a encontrar uma plataforma submersa em sala escura, tendo como referência uma fonte luminosa tênue disposta na parede norte da sala que abrigava o tanque. Esse treinamento era feito em quatro séries, sendo que em cada uma o animal era colocado na água voltado para um dos 4 pontos cardeais. Esse cuidado era feito para que o rato memorizasse a parede iluminada como ponto de referência para localizar a plataforma camuflada sob a superfície aquática, e não o encontro ao acaso da mesma pela natação em linha reta. Para avaliação da capacidade de memorização do local da plataforma, cada animal era avaliado nos dias P10 e P11, em 4 séries pela manhã e 4 séries à tarde (uma em cada ponto cardeal). Era cronometrado o tempo de nado desde que o animal era colocado na água até que subisse na plataforma. Após chegada na plataforma, era dado ao animal um tempo de descanso sobre a mesma por 15 segundos. Caso o rato não encontrasse a plataforma em 60 segundos, esse tempo era considerado como o tempo de cronometragem e o animal colocado na plataforma por 15 segundos. Outros grupos de 
pesquisadores usaram o mesmo tipo de teste para avaliação do desempenho no aprendizado e memorização de um trajeto aquático referenciado até uma plataforma submersa na hidrocefalia experimental em ratos (DEL BIGIO; WILSON; ENNO, 2003, HU et al., 2014). Na avaliação da manhã do dia P10, os animais dos diferentes grupos experimentais tiveram uma média de tempo semelhante para encontrar a plataforma. Já no período da tarde em P10 e período da manhã em P11, os animais tratados com Edaravone apresentavam uma média menor de tempo para chegar à plataforma submersa. Entretanto, na sessão da tarde do dia P11, os 3 grupos experimentais executaram o teste com média de tempo semelhante. Esses resultados podem demonstrar que os animais dos grupos HTE e C aprenderam e memorizaram o caminho para chegar à plataforma mais rapidamente que os animais hidrocefálicos que não receberam tratamento (HNT), mostrando uma tendência á maturação encefálicos. No entanto, histopatologicamente não foram encontrados resultados referentes á maturação, para estudos futuros seriam necessários testes para entender a ação do Edaravone na memorização dos ratos hidrocefálicos e análises da conectividade sináptica e metabolismo neuronal, para explicar melhor tais achados.

Através da Ressonância Magnética do encéfalo foi quantificada a razão ventricular, calculada a partir da divisão (ou razão) entre a área do ventrículo lateral no corte coronal médio e a área total do encéfalo no mesmo corte. Os ratos hidrocefálicos dos grupos HTE e HNT apresentavam ventriculomegalia de graus variados. As imagens de ressonância magnética foram correspondentes às imagens vistas posteriormente na histologia, com um aumento tanto no diâmetro látero-lateral, quanto no diâmetro vertical dos ventrículos laterais. As médias da razão ventricular dos animais dos grupos hidrocefálicos eram semelhantes, entre eles, e ambos os grupos apresentaram média significativamente maior que os animais do grupo controle. A razão ventricular apresentou uma variância muito grande nos dois grupos hidrocefálicos, indicando os variados graus de ventriculomegalia desses animais. O grau de ventriculomegalia é um fator que não conseguimos controlar, pois os animais apresentam reação inflamatória à injeção do caulim, na saída do quarto ventrículo, de intensidade variável, que pode estar relacionada às condições particulares de cada rato. Diferentes técnicas de ressonância magnética têm sido utilizadas em estudos sobre hidrocefalia, com objetivo de quantificar a mielina e avaliar a concentração dos metabolitos resultantes da degradação do tecido (YAMADA et al., 1992, BRAUN et al., 1997, CORKILL et al., 2003, YUAN et al., 2009, CASTRO et al., 2012). A transferência de magnetização (MTR) é uma técnica da ressonância magnética que vem sendo usada para quantificar a mielina presente em diferentes áreas do cérebro, mas ainda não havia sido usada por outros grupos em estudos de 
hidrocefalia experimental. Esta análise é baseada na troca de magnetização entre prótons, que estão vinculados a grandes moléculas de baixa mobilidade, como a mielina e prótons móveis em água livre (GOZZI et al., 2012). A quantificação da taxa de MTR é utilizada para investigar o grau de destruição do tecido do sistema nervoso central, em seres humanos e animais, já que as reduções nos valores de MTR são imputadas à diminuição da integridade de macromoléculas, refletindo os danos da mielina (NEWBOULD et al., 2014), da membrana axonal, ou diluição de macromoléculas em edema inflamatório (ZAARAOUI et al., 2008). Em estudo de hidrocefalia prévio, realizado por nosso grupo, a MTR foi demonstrado que a MTR está relacionada à lesão da substância branca periventricular, com valores reduzidos em relação aos controles normais. Quando os ratos hidrocefálicos eram tratados com derivação liquórica e esta estava funcionante, os valores de MTR voltavam a se aproximar daqueles obtidos nos encéfalos de ratos normais (ROCHA CATALAO et al., 2014). Nossos resultados mostram que na análise do encéfalo total os animais do grupo controle apresentavam valores de MTR ligeiramente maiores do que os animais hidrocefálicos.

$\mathrm{Na}$ análise histológica pela coloração com H\&E foi avaliada a citoarquitetura geral em diferentes regiões encefálicas (matriz germinativa, cápsula externa, córtex cerebral, corpo caloso, hipocampo). Os encéfalos dos animais pertencentes ao grupo $\mathrm{C}$ mostravam a laminação cortical preservada, sem alterações anatômicas. Nos animais hidrocefálicos apresentavam ventrículos laterais francamente aumentados e, em casos de hidrocefalia mais grave, também o terceiro ventrículo mostrava-se dilatado. O corpo caloso nesses animais mostrou-se comprimido e estirado, com sinais de edema, como esgarçamento e áreas menos coradas entre as fibras nervosas, enquanto o córtex cerebral dorsal, apesar de comprimido, manteve sua laminação preservada. É possível identificar a perda da integridade do epêndima, que apresentava suas células achatadas e com pontos de rotura, e este comprometimento foi maior conforme o nível de dilatação ventricular. Nos casos de hidrocefalia máxima, a linha mediana do encéfalo por vezes estava completamente destruída. Não percebemos diferenças evidentes entre o grupo tratado com Edaravone e o grupo com hidrocefalia sem tratamento. Portanto, acreditamos que a análise histopatológica sozinha não foi suficiente para demonstrar alterações nas estruturas que tivessem sido revertidas com o uso do Edaravone nas doses e tempos experimentais estudados.

Em 1997, Del Bigio e colaboradores usaram o mesmo método para avaliação do grau de mielinização e obtiveram resultados positivos em relação à confiabilidade da análise (DEL BIGIO; KANFER; ZHANG, 1997). Em nossa análise pela coloração por solocromo-cianina foi avaliado o grau de mielinização da substância branca periventricular, 
corada em azul pelo método. Como a intensidade do azul é diretamente proporcional ao grau de mielinização, foi possível relacionar a lesão da hidrocefalia com a perda da mielina e avaliar se a droga testada proporcionou algum efeito na mielinização. Os animais do grupo controle exibiam uma tonalidade significantemente mais intensa em azul no corpo caloso, quando comparados com os grupos hidrocefálicos (HTE e HNT). Quando confrontamos o corpo caloso dos animais dos dois grupos hidrocefálicos pudemos observar que a intensidade de coloração em azul parecia mais intensa nos ratos tratados com Edaravone, sugerindo melhor padrão de mielinização dessa região, que poderia ser resultante do efeito neuroprotetor da droga. Entretanto, quando atribuímos um score de classificação de intensidade de coloração azul, tornando esta avaliação menos subjetiva, não observamos diferença significativa entre os animais hidrocefálicos tratados e não tratados.

Para associar o grau da ventriculomegalia com a gravidade da lesão do corpo caloso (estrutura mais próxima das cavidades dos ventrículos laterais), foram realizadas medidas da espessura do mesmo. Na comparação entre os grupos (HNT, HTE e C), observouse maior espessura do corpo caloso nos animais controles, com diferença estatística significativa. Já na comparação entre os grupos HTE e HNT não foi encontrada diferença significativa. A proposta de nosso trabalho não foi usar o Edaravone para impedir a progressão da dilatação ventricular, mas sim atenuar as lesões no parênquima cerebral resultantes da geração de radicais livres.

Astrócitos são células da neuroglia amplamente distribuídas por todo sistema nervoso central, seja na substância branca, seja na substância cinzenta. Desempenham funções importantes, tais como a sustentação e a nutrição dos neurônios, além de serem reguladores das funções neuronais. Os astrócitos são ativados em situações de agressão ao sistema nervoso central, em resposta defensiva, limitando e reparando os danos ao tecido, e restaurando a homeostase. Uma das características observadas durante a ativação glial é a expressão aumentada do GFAP, em um processo chamado astrogliose reativa, que ocorre em situações como trauma, desordens genéticas, insultos químicos e doenças neurodegenerativas (PEKNY; PEKNA, 2014). Nossos resultados da análise histopatológica por imunoistoquímica para o GFAP demonstraram que os astrócitos imunomarcados, nas diferentes regiões estudadas nos ratos com hidrocefalia sem tratamento, apresentavam-se intensamente marcados e com prolongamentos espessos. Já nos animais hidrocefálicos tratados com Edaravone, os astrócitos eram mais delicados com prolongamentos mais finos, apesar de termos observado imunomarcação astrocitária mais intensa que nos ratos controles. Este aspecto mais grosseiro dos astrócitos deve-se justamente ao fato dessas células estarem 
ativadas para realizarem a reparação e a cicatrização do sistema nervoso central, nos mais diferentes tipos de agressão. Entretanto, além da análise qualitativa, fizemos a contagem e o cálculo da densidade dos astrócitos reativos no corpo caloso e na matriz germinativa, áreas escolhidas porque apresentaram astrogliose mais evidente. Nossos resultados mostraram não haver diferença significante na densidade astrocitária nessas regiões entre os grupos hidrocefálicos HTE e HNT. Esses achados sugerem que o Edaravone possa ter exercido um papel neuroprotetor mínimo, quando considerada a intensidade da reação astrocitária, porém o número de astrócitos imunomarcados foi o semelhante nos dois grupos. Em outros modelos de lesão do tecido nervoso, como na isquemia cerebral e traumatismo crânio-encefálico, o Edaravone mostrou ser eficiente na redução das lesões, por agir nos mecanismos biomoleculares relacionados ao estresse oxidativo (WANG et al., 2011, REN et al., 2014). O fato de termos encontrado melhora apenas discreta nas lesões cerebrais pode significar que o estresse oxidativo pode não representar um mecanismo muito importante na gênese dessas lesões e, portanto, uma droga com ação antioxidante não tem um papel relevante na neuroproteção.

$\mathrm{Na}$ análise de células em divisão mitótica imunomarcadas por Ki-67, examinamos a região da matriz germinativa (localizada no ângulo externo dos ventrículos laterais do cérebro, região de intensa proliferação celular), ainda presente em ratos jovens. Observamos que os animais do grupo controle apresentavam intensa celularidade nesta região, com um grande número de células imunomarcadas pelo Ki-67. Já os animais hidrocefálicos, tratados e não tratados com Edaravone, apresentaram imunomarcação menos evidente, com uma celularidade reduzida na região estudada, e, após a contagem das células imunomarcadas, não observamos diferença significativa entre esses dois grupos hidrocefálicos. Podemos, então, constatar que o Edaravone, na dose testada e no tempo experimental de observação, não mostrou ser suficiente na proteção da região da matriz germinativa. Já em um estudo com animais hidrocefálicos tratados com quercetina, um fármaco com grande ação antioxidante, foi observado um aumento marcante na proliferação de células, analisado por imunomarcação para Ki-67 nas células das paredes dos ventrículos laterais. Os autores afirmam que o acúmulo de espécies reativas de oxigênio prejudica a proliferação e a auto-renovação de células-tronco neurais, e o antioxidante testado pode agir cooperando no restabelecimento da homeostase e evitando danos celulares (LI, X. et al., 2014). O fato de não termos observado uma recuperação na celularidade na região da matriz germinativa com o uso do Edaravone pode indicar que a dose da droga por nós usada não foi suficiente para obtenção dos efeitos benéficos. 
Na análise pela marcação de caspase-3 foram estudadas as regiões do corpo caloso e córtex cerebral dorsal ao corpo caloso. Através de uma varredura nestas áreas, contabilizamos todas as células imunomarcadas (em processos de apoptose). Não observamos diferença na contagem de células marcadas pela caspase-3 no corpo caloso entre os três grupos analisados. Por outro lado, no córtex dorsal, observamos que o grupo HNT apresentou um número maior de células em apoptose, quando comparado aos grupos HTE e C. Tais resultados sugerem um efeito benéfico do Edaravone nos animais hidrocefálicos, por reduzir a morte celular por apoptose no córtex cerebral. Alguns autores já sugeriram que o Edaravone, além do efeito antioxidante na isquemia cerebral, apresenta um papel relevante na redução da apoptose e consequente morte celular (LI, Q. et al., 2014). Como encontramos diferença na contagem de células em apoptose imunomarcadas pela caspase-3 somente no córtex cerebral dorsal ao corpo caloso, mas não no próprio corpo caloso, podemos deduzir que essas células em morte cerebral são neurônios. Entretanto, será necessária imunoistoquímica com dupla marcação para confirmação.

A micróglia corresponde ao conjunto de células do sistema imunológico no sistema nervoso central e desempenha um papel crucial, tanto fisiológico quanto em condições patológicas, tais como a restauração da integridade do sistema nervoso central e desaceleração na progressão de doenças neurodegenerativas. O papel fisiológico da micróglia no desenvolvimento do cérebro ainda é em grande parte desconhecido. Sabe-se que durante o desenvolvimento é capaz de fagocitar e atuar na regulação da apoptose, proliferação celular, diferenciação neuronal e angiogênese. Também pode ter uma dupla função como mediadora da inflamação e auxiliar no processo de recuperação após danos do sistema nervoso central (CZEH; GRESSENS; KAINDL, 2011). Nos nossos resultados referentes à avaliação da reação das células da micróglia através da marcação por lectina, não encontramos diferença na contagem dessas células no córtex cerebral dorsal ao corpo caloso entre os 3 grupos estudados. Já no corpo caloso, os animais do grupo HNT apresentavam uma média significantemente maior de células com reação microglial, quando comparados com os ratos do grupo C. Por outro lado a média da contagem de células marcadas pela lectina no corpo caloso do grupo HTE não foi estatisticamente diferente, quando comparado tanto com o grupo HNT quanto com o grupo controle. Com a ventriculomegalia, o corpo caloso é a estrutura mais lesionada, por ser umas das mais próximas a região dos ventrículos laterais, assim tendo mais ação das células da microglia. A ação benéfica do Edaravone parece ter sido apenas discreta, pois a contagem de células marcadas pela lectina no corpo caloso dos ratos do grupo 
HTE ficou entre a contagem dos grupos controle e HNT, sem apresentar, entretanto, diferença significativa.

Vários radicais livres de oxigênio, incluindo o superóxido, o radical hidroxilo, o óxido nítrico e o peróxido de hidrogênio, foram implicados no desenvolvimento de vários distúrbios neurológicos e disfunções cerebrais (SIESJO; AGARDH; BENGTSSON, 1989, CHAN, 1994). Estes radicais são conhecidos por iniciar a peroxidação lipídica e causar oxidação de proteínas, e dano ao DNA das células. Doenças com lesão por isquemia cerebral global estão relacionadas com o estresse oxidativo causado pela produção excessiva de EROS e outros radicais livres (NISHINO; TAMURA, 1991). Os mecanismos enzimáticos e não enzimáticos são a defesa que o sistema nervoso central tem para prevenir o estresse oxidativo. Quando não há "limpeza" efetiva pelos sistemas antioxidantes, os radicais livres começam a se acumular e a danificar o tecido. Estudos sugerem que o dano oxidativo cerebral pode representar um fator importante na patogênese da hidrocefalia (DI CURZIO; TURNERBRANNEN; DEL BIGIO, 2014, LI, X. et al., 2014). Outros pesquisadores ainda sugerem que o Edaravone é um grande agente antioxidante, que inibe a geração de radicais livres, assim evitando a morte celular induzida pelo estresse oxidativo (SHOKRZADEH et al., 2014, TSURUOKA et al., 2014).

$\mathrm{Na}$ tentativa de associar o uso do Edaravone e a neuroproteção na hidrocefalia, fizemos dosagens de antioxidantes totais presentes no plasma, quantificamos a peroxidação lipídica e a atividade de uma enzima envolvida no processo de regulação da produção de radicais livres, no tecido cerebral.

$\mathrm{Na}$ quantificação dos antioxidantes totais do plasma não foi observada diferença entre os dois grupos hidrocefálicos. Por outro lado, o grupo controle exibiu uma quantidade significativamente maior de antioxidantes no plasma que os dois grupos de ratos com hidrocefalia. A glutationa peroxidase é uma enzima endógena que tem ação antioxidante, e é encontrada em todas as células animais. Seu nível é reduzido mediante a presença dos radicais livres e estresse oxidativo, pois é consumida na regulação e limpeza desses produtos. Neste estudo foram feitas dosagens dessa enzima no tecido encefálico e considerado seu consumo no decorrer do tempo. Na comparação entre os três grupos experimentais não foram encontradas diferenças significantes das médias.

Sabe-se que os produtos de peroxidação lipídica aumentam logo após uma agressão tecidual. O (MDA) é formado a partir da quebra de ácidos graxos poliinsaturados e serve como um indicador conveniente para determinar a extensão da peroxidação lipídica. Para avaliação dos níveis de malondialdeído utilizamos a medição de substâncias reativas ao 
ácido tiobarbitúrico. Também não encontramos diferenças significantes na média do nível de MDA entre os 3 grupos analisados. $\mathrm{O}$ fato de não termos encontrado níveis de antioxidantes que pudessem sugerir a ação benéfica do Edaravone pode significar que a dose que usamos pode não ter sido suficiente para aumentar a quantidade de antioxidantes no plasma e no tecido, já que não fizemos estudo de dose-dependência . De maneira semelhante, outro estudo usando um conjunto de fármacos antioxidantes, mostrou que animais hidrocefálicos tratados não obtiveram um aumento nos níveis de MDA (DI CURZIO; TURNER-BRANNEN; DEL BIGIO, 2014).

Na dose testada o Edaravone não mostrou um efeito antioxidante relevante, apesar de termos observado um papel benéfico na morte celular por apoptose. Portanto, outras doses da droga merecem ser testadas. Por outro lado, sabemos que a isquemia cerebral é um dos mecanismos de lesão tecidual na hidrocefalia, ocorrendo por compressão e distorção dos vasos cerebrais, especialmente os vasos de menor calibre, e a presença de níveis elevados de radicais livres na hidrocefalia pode estar associada à reperfusão após a colocação do shunt para seu tratamento. Assim, estudos adicionais devem ser feitos associando o tratamento da hidrocefalia com derivação liquórica e o uso do Edaravone. 
7. CONCLUSÕES 
1. Os animais tratados com Edaravone mostravam ser mais ativos, com um maior desempenho para exploração do ambiente e um melhor desenvolvimento sensoriomotor, aprendizagem e de memorização.

2. A avaliação histológica por solocromo-cianina comprova o papel prejudicial que a hidrocefalia exerce sobre a mielinização das estruturas.

3. O Edaravone administrado por 14 dias consecutivos a partir da indução da hidrocefalia reduziu a atividade astrocitária evidenciada pela imunomarcação do GFAP no corpo caloso e na matriz germinativa.

4. A dilatação ventricular progressiva na hidrocefalia contribui para o desaparecimento das células migratórias na região da matriz germinativa evidenciada pela imunomarcação do Ki67.

5. O Edaravone não mostrou uma atividade antioxidante nas doses testadas, mas uma ação neuroprotetora contra a morte celular por apoptose e uma diminuição na reação microglial do corpo caloso.

6. Na dose testada, o Edaravone não mostrou elevação dos níveis de antioxidantes totais, necessitando de estudos com outras doses. 


\section{REFERÊNCIAS}


ATES, O.; CAYLI, S.; ALTINOZ, E.; GURSES, I.; YUCEL, N.; SENER, M.; KOCAK, A.; YOLOGLU, S. Neuroprotection by resveratrol against traumatic brain injury in rats. Mol Cell Biochem, v. 294, n. 1-2, Jan, p.137-144. 2007.

BANNO, M.; MIZUNO, T.; KATO, H.; ZHANG, G.; KAWANOKUCHI, J.; WANG, J.; KUNO, R.; JIN, S.; TAKEUCHI, H.; SUZUMURA, A. The radical scavenger Edaravone prevents oxidative neurotoxicity induced by peroxynitrite and activated microglia. Neuropharmacology, v. 48, n. 2, Feb, p.283-290. 2005.

BONDURANT, C. P.; JIMENEZ, D. F. Epidemiology of cerebrospinal fluid shunting. Pediatr Neurosurg, v. 23, n. 5, p.254-258; discussion 259. 1995.

BRAUN, K. P.; DE GRAAF, R. A.; VANDERTOP, W. P.; GOOSKENS, R. H.; TULLEKEN, K. A.; NICOLAY, K. In vivo $1 \mathrm{H}$ MR spectroscopic imaging and diffusion weighted MRI in experimental hydrocephalus. Magn Reson Med, v. 40, n. 6, Dec, p.832839. 1998.

BRAUN, K. P.; DIJKHUIZEN, R. M.; DE GRAAF, R. A.; NICOLAY, K.; VANDERTOP, W. P.; GOOSKENS, R. H.; TULLEKEN, K. A. Cerebral ischemia and white matter edema in experimental hydrocephalus: a combined in vivo MRI and MRS study. Brain Res, v. 757, n. 2, May 23, p.295-298. 1997.

CANER, H.; ATASEVER, A.; KILINC, K.; DURGUN, B.; PEKER, S.; OZCAN, O. E. Lipid peroxide level increase in experimental hydrocephalus. Acta Neurochir (Wien), v. 121, n. 12, p.68-71. 1993.

CASTRO-GAGO, M.; RODRIGUEZ, I. N.; RODRIGUEZ-NUNEZ, A.; GUITIAN, J. P.; ROCAMONDE, S. L.; RODRIGUEZ-SEGADE, S. Therapeutic criteria in hydrocephalic children. Childs Nerv Syst, v. 5, n. 6, Dec, p.361-363. 1989.

CASTRO, S. C.; MACHADO, H. R.; CATALAO, C. H.; SIQUEIRA, B. A.; SIMOES, A. L.; LACHAT, J. J.; LOPES LDA, S. 0.1T magnetic resonance image in the study of experimental hydrocephalus in rats. Accuracy of the method in the measurements of the ventricular size. Acta Cir Bras, v. 27, n. 11, Nov, p.768-772. 2012.

CATALAO, C. H.; CORREA, D. A.; SAITO, S. T.; LOPES LDA, S. Camellia sinensis neuroprotective role in experimentally induced hydrocephalus in Wistar rats. Childs Nerv Syst, v. 30, n. 4, Apr, p.591-597. 2014.

CHAN, P. H. Oxygen radicals in focal cerebral ischemia. Brain Pathol, v. 4, n. 1, Jan, p.5965. 1994.

CORKILL, R. G.; GARNETT, M. R.; BLAMIRE, A. M.; RAJAGOPALAN, B.; CADOUXHUDSON, T. A.; STYLES, P. Multi-modal MRI in normal pressure hydrocephalus identifies pre-operative haemodynamic and diffusion coefficient changes in normal appearing white matter correlating with surgical outcome. Clin Neurol Neurosurg, v. 105, n. 3, Jul, p.193202. 2003. 
CZEH, M.; GRESSENS, P.; KAINDL, A. M. The yin and yang of microglia. Dev Neurosci, v. 33, n. 3-4, p.199-209. 2011.

DEFEO, D. R.; MYERS, P.; FOLTZ, E. L.; EVERETT, B.; RAMSHAW, B. Histological examination of kaolin-induced hydrocephalus. Its implications in the therapy of animals with experimentally induced hydrocephalus. J Neurosurg, v. 50, n. 1, Jan, p.7O-4. 1979.

DEL BIGIO, M. R.; BRUNI, J. E.; FEWER, H. D. Human neonatal hydrocephalus. An electron microscopic study of the periventricular tissue. J Neurosurg, v. 63, n. 1, Jul, p.56-63. 1985.

DEL BIGIO, M. R.; KANFER, J. N.; ZHANG, Y. W. Myelination delay in the cerebral white matter of immature rats with kaolin-induced hydrocephalus is reversible. J Neuropathol Exp Neurol, v. 56, n. 9, Sep, p.1053-1066. 1997.

DEL BIGIO, M. R.; MCALLISTER II, J. P. Hydrocephalus - Pathology. In: CHOUX, M., DI ROCCO, C. AL, E. Pediatric Neurosurgery. Londres: Churchill Livingstoneed., 1999, p.217236

DEL BIGIO, M. R.; WILSON, M. J.; ENNO, T. Chronic hydrocephalus in rats and humans: white matter loss and behavior changes. Ann Neurol, v. 53, n. 3, Mar, p.337-346. 2003.

DEVARAJ, S.; TANG, R.; ADAMS-HUET, B.; HARRIS, A.; SEENIVASAN, T.; DE LEMOS, J. A.; JIALAL, I. Effect of high-dose alpha-tocopherol supplementation on biomarkers of oxidative stress and inflammation and carotid atherosclerosis in patients with coronary artery disease. Am J Clin Nutr, v. 86, n. 5, Nov, p.1392-1398. 2007.

DI CURZIO, D. L.; TURNER-BRANNEN, E.; DEL BIGIO, M. R. Oral antioxidant therapy for juvenile rats with kaolin-induced hydrocephalus. Fluids Barriers CNS, v. 11, n., p.23. 2014.

DOHARE, P.; HYZINSKI-GARCIA, M. C.; VIPANI, A.; BOWENS, N. H.; NALWALK, J. W.; FEUSTEL, P. J.; KELLER, R. W., JR.; JOURD'HEUIL, D.; MONGIN, A. A. The neuroprotective properties of the superoxide dismutase mimetic tempol correlate with its ability to reduce pathological glutamate release in a rodent model of stroke. Free Radic Biol Med, v., n., Sep 12. 2014.

DRINGEN, R.; GUTTERER, J. M.; HIRRLINGER, J. Glutathione metabolism in brain metabolic interaction between astrocytes and neurons in the defense against reactive oxygen species. Eur J Biochem, v. 267, n. 16, Aug, p.4912-4916. 2000.

EDWARDS, M. S.; HARRISON, M. R.; HALKS-MILLER, M.; NAKAYAMA, D. K.; BERGER, M. S.; GLICK, P. L.; CHINN, D. H. Kaolin-induced congenital hydrocephalus in utero in fetal lambs and rhesus monkeys. J Neurosurg, v. 60, n. 1, Jan, p.115-122. 1984.

FERSTEN, E.; GORDON-KRAJCER, W.; GLOWACKI, M.; MROZIAK, B.; JURKIEWICZ, J.; CZERNICKI, Z. Cerebrospinal fluid free-radical peroxidation products and cognitive functioning patterns differentiate varieties of normal pressure hydrocephalus. Folia Neuropathol, v. 42, n. 3, p.133-140. 2004. 
GARNE, E.; LOANE, M.; ADDOR, M. C.; BOYD, P. A.; BARISIC, I.; DOLK, H. Congenital hydrocephalus--prevalence, prenatal diagnosis and outcome of pregnancy in four European regions. Eur J Paediatr Neurol, v. 14, n. 2, Mar, p.150-155. 2010.

GOZZI, M.; NIELSON, D. M.; LENROOT, R. K.; OSTUNI, J. L.; LUCKENBAUGH, D. A.; THURM, A. E.; GIEDD, J. N.; SWEDO, S. E. A magnetization transfer imaging study of corpus callosum myelination in young children with autism. Biol Psychiatry, v. 72, n. 3, Aug 1, p.215-220. 2012.

HALLIWELL, B.; WHITEMAN, M. Measuring reactive species and oxidative damage in vivo and in cell culture: how should you do it and what do the results mean? Br J Pharmacol, v. 142 , n. 2004.

HALLIWELL, B. G., J. M. C. . Free Radicals in Biology and Medicine. . New York: Oxford. 2007

HIGASHI, Y.; JITSUIKI, D.; CHAYAMA, K.; YOSHIZUMI, M. Edaravone (3-methyl-1phenyl-2-pyrazolin-5-one), a novel free radical scavenger, for treatment of cardiovascular diseases. Recent Pat Cardiovasc Drug Discov, v. 1, n. 1, Jan, p.85-93. 2006.

HOCHWALD, G. M. Animal models of hydrocephalus: recent developments. Proc Soc Exp Biol Med, v. 178, n. 1, Jan, p.1-11. 1985.

HU, Q.; VAKHMJANIN, A.; LI, B.; TANG, J.; ZHANG, J. H. Hyperbaric oxygen therapy fails to reduce hydrocephalus formation following subarachnoid hemorrhage in rats. Med Gas Res, v. 4, n., p.12. 2014.

INOUE, Y.; YABE, T.; OKADA, K.; NAKAMURA, Y. Effect of Edaravone on acute brainstem-cerebellar infarction with vertigo and sudden hearing loss. Auris Nasus Larynx, v. 41, n. 3, Jun, p.303-306. 2014.

ISHIBASHI, A.; YOSHITAKE, Y.; ADACHI, H. Investigation of effect of Edaravone on ischemic stroke. Kurume Med J, v. 60, n. 2, p.53-57. 2013.

ISHIKAWA, A.; YOSHIDA, H.; METOKI, N.; TOKI, T.; IMAIZUMI, T.; MATSUMIYA, T.; YAMASHITA, K.; TAIMA, K.; SATOH, K. Edaravone inhibits the expression of vascular endothelial growth factor in human astrocytes exposed to hypoxia. Neurosci Res, v. 59, n. 4, Dec, p.406-412. 2007.

ITO, H.; WATE, R.; ZHANG, J.; OHNISHI, S.; KANEKO, S.; NAKANO, S.; KUSAKA, H. Treatment with Edaravone, initiated at symptom onset, slows motor decline and decreases SOD1 deposition in ALS mice. Exp Neurol, v. 213, n. 2, Oct, p.448-455. 2008.

ITOH, T.; SATOU, T.; NISHIDA, S.; TSUBAKI, M.; HASHIMOTO, S.; ITO, H. The novel free radical scavenger, Edaravone, increases neural stem cell number around the area of damage following rat traumatic brain injury. Neurotox Res, v. 16, n. 4, Nov, p.378-389. 2009. 
JUCÁ, C. E. B.; LINS NETO, A.; OLIVEIRA, R. S.; MACHADO, H. R. Treatment of hydrocephalus by ventriculoperitoneal shunt: analysis of 150 consecutive cases in the hospital of the faculty of medicine of Ribeirão Preto. Acta Cir Bras, v. 17, n., p.59-63. 2002.

JULIAN-REYNIER，C.; PHILIP， N.; SCHEINER， C.; AURRAN，Y.; CHABAL，F.; MARON, A.; GOMBERT, A.; AYME, S. Impact of prenatal diagnosis by ultrasound on the prevalence of congenital anomalies at birth in southern France. J Epidemiol Community Health, v. 48, n. 3, Jun, p.290-296. 1994.

KAMIDA, T.; FUJIKI, M.; OOBA, H.; ANAN, M.; ABE, T.; KOBAYASHI, H. Neuroprotective effects of Edaravone, a free radical scavenger, on the rat hippocampus after pilocarpine-induced status epilepticus. Seizure, v. 18, n. 1, Jan, p.71-75. 2009.

KHAN, O. H.; ENNO, T. L.; DEL BIGIO, M. R. Brain damage in neonatal rats following kaolin induction of hydrocephalus. Exp Neurol, v. 200, n. 2, Aug, p.311-320. 2006.

KIEFER, M.; EYMANN, R.; VON TILING, S.; MULLER, A.; STEUDEL, W. I.; BOOZ, K. H. The ependyma in chronic hydrocephalus. Childs Nerv Syst, v. 14, n. 6, Jun, p.263-270. 1998.

KIKUCHI, K.; MIURA, N.; KAWAHARA, K. I.; MURAI, Y.; MORIOKA, M.; LAPCHAK, P. A.; TANAKA, E. Edaravone (Radicut), a free radical scavenger, is a potentially useful addition to thrombolytic therapy in patients with acute ischemic stroke. Biomed Rep, v. 1, n. 1, Jan, p.7-12. 2013.

LEE, M. J.; MALIAKAL, P.; CHEN, L.; MENG, X.; BONDOC, F. Y.; PRABHU, S.; LAMBERT, G.; MOHR, S.; YANG, C. S. Pharmacokinetics of tea catechins after ingestion of green tea and (-)-epigallocatechin-3-gallate by humans: formation of different metabolites and individual variability. Cancer Epidemiol Biomarkers Prev, v. 11, n. $10 \mathrm{Pt}$ 1, Oct, p.1025-1032. 2002.

LI, Q.; BI, M. J.; BI, W. K.; KANG, H.; YAN, L. J.; GUO, Y. L. Edaravone attenuates brain damage in rats after acute $\mathrm{CO}$ poisoning through inhibiting apoptosis and oxidative stress. Environ Toxicol, v., n., Oct 28. 2014.

LI, X.; LI, L.; LI, J.; SIPPLE, J.; SCHICK, J.; MEHTA, P. A.; DAVIES, S. M.; DASGUPTA, B.; WACLAW, R. R.; PANG, Q. Concomitant Inactivation of Foxo3a and Fance or Fancd2 Reveals a Two-Tier Protection from Oxidative Stress-Induced Hydrocephalus. Antioxid Redox Signal, v., n., Mar 12. 2014.

LOPES, L., S.; SLOBODIAN, I.; DEL BIGIO, M. R. Characterization of juvenile and young adult mice following induction of hydrocephalus with kaolin. Exp Neurol, v. 219, n. 1, Sep, p.187-196. 2009.

MABE, H.; SUZUKI, K.; NAGAI, H. Cerebral blood flow after ventriculoperitoneal shunt in children with hydrocephalus. Childs Nerv Syst, v. 6, n. 7, Nov, p.388-391. 1990.

MCLONE, D. G. Consensus: modelling of hydrocephalus. Childs Nerv Syst, v. 10, n. 1, Jan, p.24-28. 1994. 
MILHORAT, T. H. Pediatric Neurosurgery. 2 ed. Philadelphia: F. A. Davis Co. 1979

MORI, K.; MIYAKE, H.; KURISAKA, M.; SAKAMOTO, T. Immunohistochemical localization of superoxide dismutase in congenital hydrocephalic rat brain. Childs Nerv Syst, v. 9, n. 3, Jun, p.136-141. 1993.

MUNAKATA, A.; OHKUMA, H.; NAKANO, T.; SHIMAMURA, N.; ASANO, K.; NARAOKA, M. Effect of a free radical scavenger, Edaravone, in the treatment of patients with aneurysmal subarachnoid hemorrhage. Neurosurgery, v. 64, n. 3, Mar, p.423-428; discussion 428-429. 2009.

NAKAMURA, T.; KURODA, Y.; YAMASHITA, S.; ZHANG, X.; MIYAMOTO, O.; TAMIYA, T.; NAGAO, S.; XI, G.; KEEP, R. F.; ITANO, T. Edaravone attenuates brain edema and neurologic deficits in a rat model of acute intracerebral hemorrhage. Stroke, v. 39, n. 2, Feb, p.463-469. 2008.

NEWBOULD, R. D.; NICHOLAS, R.; THOMAS, C. L.; QUEST, R.; LEE, J. S.; HONEYFIELD, L.; COLASANTI, A.; MALIK, O.; MATTOSCIO, M.; MATTHEWS, P. M.; SORMANI, M. P.; WALDMAN, A. D.; MURARO, P. A. Age independently affects myelin integrity as detected by magnetization transfer magnetic resonance imaging in multiple sclerosis. Neuroimage Clin, v. 4, n., p.641-648. 2014.

NISHINO, T.; TAMURA, I. The mechanism of conversion of xanthine dehydrogenase to oxidase and the role of the enzyme in reperfusion injury. Adv Exp Med Biol, v. 309A, n., p.327-333. 1991.

NOOR, J. I.; IKEDA, T.; MISHIMA, K.; AOO, N.; OHTA, S.; EGASHIRA, N.; IWASAKI, K.; FUJIWARA, M.; IKENOUE, T. Short-term administration of a new free radical scavenger, Edaravone, is more effective than its long-term administration for the treatment of neonatal hypoxic-ischemic encephalopathy. Stroke, v. 36, n. 11, Nov, p.2468-2474. 2005.

OHTA, Y.; TAKAMATSU, K.; FUKUSHIMA, T.; IKEGAMI, S.; TAKEDA, I.; OTA, T.; GOTO, K.; ABE, K. Efficacy of the free radical scavenger, Edaravone, for motor palsy of acute lacunar infarction. Intern Med, v. 48, n. 8, p.593-596. 2009.

PEKNY, M.; PEKNA, M. Astrocyte Reactivity and Reactive Astrogliosis: Costs and Benefits. Physiol Rev, v. 94, n. 4, Oct, p.1077-1098. 2014.

PORTNOY, H. D.; BRANCH, C.; CASTRO, M. E. The relationship of intracranial venous pressure to hydrocephalus. Childs Nerv Syst, v. 10, n. 1, Jan, p.29-35. 1994.

REN, Y.; WEI, B.; SONG, X.; AN, N.; ZHOU, Y.; JIN, X.; ZHANG, Y. Edaravone's free radical scavenging mechanisms of neuroprotection against cerebral ischemia: review of the literature. Int J Neurosci, v., n., Sep 24. 2014.

ROCHA CATALAO, C. H.; LEME CORREA, D. A.; BERNARDINO GARCIA, C. A.; DOS SANTOS, A. C.; GARRIDO SALMON, C. E.; ALVES ROCHA, M. J.; DA SILVA LOPES, L. Pre- and postshunting magnetization transfer ratios are in accordance with neurological and behavioral changes in hydrocephalic immature rats. Dev Neurosci, v. 36, n. 6, p.520-531. 2014. 
SATO, O.; OI, S.; YAMADA, S. Hydrocephalus: experimental considerations and clinical analyses. In: CHOUX, M., DI ROCCO, C., HOCKLEY, A. WALKER, M. Pediatric neurosurgery. London: , 1999:237-252.: Churchill Livingstoneed., 1999

SHOESMITH, C. L.; BUIST, R.; DEL BIGIO, M. R. Magnetic resonance imaging study of extracellular fluid tracer movement in brains of immature rats with hydrocephalus. Neurol Res, v. 22, n. 1, Jan, p.111-116. 2000.

SHOKRZADEH, M.; SHAKI, F.; MOHAMMADI, E.; REZAGHOLIZADEH, N.; EBRAHIMI, F. Edaravone decreases paraquat toxicity in a549 cells and lung isolated mitochondria. Iran J Pharm Res, v. 13, n. 2, Spring, p.675-681. 2014.

SIES, H. Oxidative stress: oxidants and antioxidants. Exp Physiol, v. 82, n. 2, Mar, p.291295. 1997.

SIESJO, B. K.; AGARDH, C. D.; BENGTSSON, F. Free radicals and brain damage. Cerebrovasc Brain Metab Rev, v. 1, n. 3, Fall, p.165-211. 1989.

TATEM, K. S.; QUINN, J. L.; PHADKE, A.; YU, Q.; GORDISH-DRESSMAN, H.; NAGARAJU, K. Behavioral and locomotor measurements using an open field activity monitoring system for skeletal muscle diseases. J Vis Exp, v., n. 91. 2014.

TOYODA, K.; FUJII, K.; KAMOUCHI, M.; NAKANE, H.; ARIHIRO, S.; OKADA, Y.; IBAYASHI, S.; IIDA, M. Free radical scavenger, Edaravone, in stroke with internal carotid artery occlusion. J Neurol Sci, v. 221, n. 1-2, Jun 15, p.11-17. 2004.

TSURUOKA, A.; ATSUMI, C.; MIZUKAMI, H.; IMAI, T.; HAGIWARA, Y.; HASEGAWA, Y. Effects of Edaravone, a Free Radical Scavenger, on Circulating Levels of MMP-9 and Hemorrhagic Transformation in Patients with Intravenous Thrombolysis Using Low-dose Alteplase. J Stroke Cerebrovasc Dis, v., n., Oct 1. 2014.

VOGEL, P.; READ, R. W.; HANSEN, G. M.; PAYNE, B. J.; SMALL, D.; SANDS, A. T.; ZAMBROWICZ, B. P. Congenital hydrocephalus in genetically engineered mice. Vet Pathol, v. 49, n. 1, Jan, p.166-181. 2012.

WANG, G. H.; JIANG, Z. L.; LI, Y. C.; LI, X.; SHI, H.; GAO, Y. Q.; VOSLER, P. S.; CHEN, J. Free-radical scavenger Edaravone treatment confers neuroprotection against traumatic brain injury in rats. J Neurotrauma, v. 28, n. 10, Oct, p.2123-2134. 2011.

WANG, J.; GUO, G.; WANG, W.; TANG, Y.; SHUN, J.; ZHOU, X.; ZHANG, P. Effect of methylprednisolone and Edaravone administration on spinal cord injury. Eur Rev Med Pharmacol Sci, v. 17, n. 20, Oct, p.2766-2772. 2013.

WATANABE, T.; TAHARA, M.; TODO, S. The novel antioxidant Edaravone: from bench to bedside. Cardiovasc Ther, v. 26, n. 2, Summer, p.101-114. 2008.

WU, T. W.; ZENG, L. H.; WU, J.; FUNG, K. P. MCI-186: further histochemical and biochemical evidence of neuroprotection. Life Sci, v. 67, n. 19, Sep 29, p.2387-2392. 2000. 
YAGI, K.; KITAZATO, K. T.; UNO, M.; TADA, Y.; KINOUCHI, T.; SHIMADA, K.; NAGAHIRO, S. Edaravone, a free radical scavenger, inhibits MMP-9-related brain hemorrhage in rats treated with tissue plasminogen activator. Stroke, v. 40, n. 2, Feb, p.626631. 2009.

YAMADA, H.; YOKOTA, A.; FURUTA, A.; HORIE, A. Reconstitution of shunted mantle in experimental hydrocephalus. J Neurosurg, v. 76, n. 5, May, p.856-862. 1992.

YOSHIDA, H.; YANAI, H.; NAMIKI, Y.; FUKATSU-SASAKI, K.; FURUTANI, N.; TADA, N. Neuroprotective effects of Edaravone: a novel free radical scavenger in cerebrovascular injury. CNS Drug Rev, v. 12, n. 1, Spring, p.9-20. 2006.

YUAN, W.; MANGANO, F. T.; AIR, E. L.; HOLLAND, S. K.; JONES, B. V.; ALTAYE, M.; BIERBRAUER, K. Anisotropic diffusion properties in infants with hydrocephalus: a diffusion tensor imaging study. AJNR Am J Neuroradiol, v. 30, n. 9, Oct, p.1792-1798. 2009.

ZAARAOUI, W.; DELOIRE, M.; MERLE, M.; GIRARD, C.; RAFFARD, G.; BIRAN, M.; INGLESE, M.; PETRY, K. G.; GONEN, O.; BROCHET, B.; FRANCONI, J. M.; DOUSSET, $\mathrm{V}$. Monitoring demyelination and remyelination by magnetization transfer imaging in the mouse brain at 9.4 T. MAGMA, v. 21, n. 5, Sep, p.357-362. 2008.

ZAGER, E. L.; AMES, A., 3RD. Reduction of cellular energy requirements. Screening for agents that may protect against CNS ischemia. J Neurosurg, v. 69, n. 4, Oct, p.568-579. 1988.

ZHANG, N.; KOMINE-KOBAYASHI, M.; TANAKA, R.; LIU, M.; MIZUNO, Y.; URABE, T. Edaravone reduces early accumulation of oxidative products and sequential inflammatory responses after transient focal ischemia in mice brain. Stroke, v. 36, n. 10, Oct, p.2220-2225. 2005. 
ANEXOS 


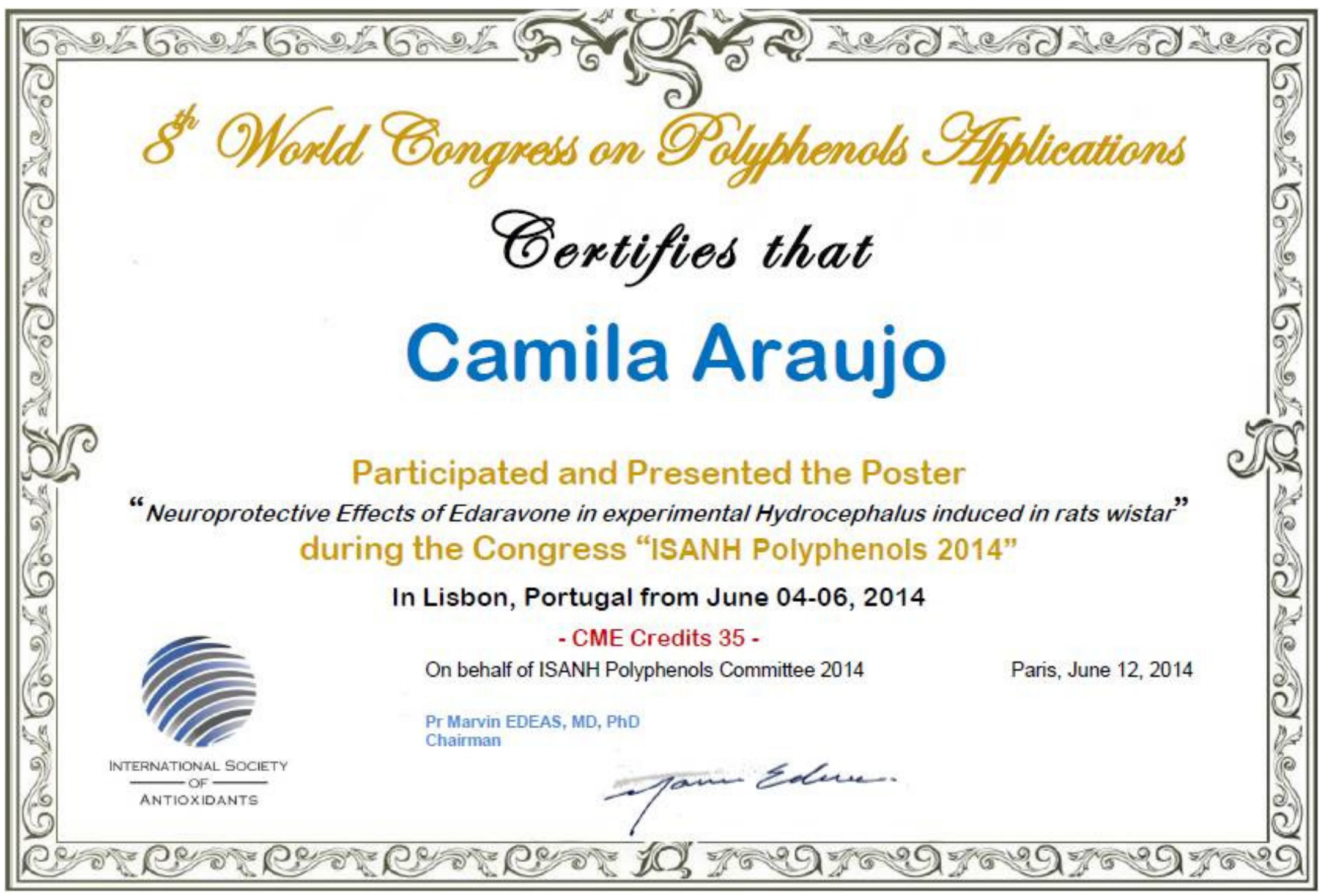




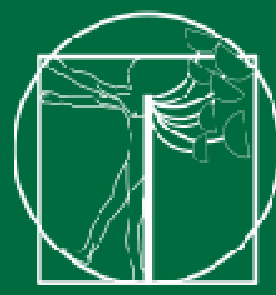

\section{Congresso} Brasileiro de Anatomia

\section{Gertificado}

II Encontro de Ligas Estudantis de Morfologia

29 de SET. a 02 de OUT. de 2014 Curitiba / PR

Certificamos que o trabalho intitulado:

EFEITOS NEUROPROTETORES DO EDARAVONE NA HIDROCEFALIA EXPERIMENTAL INDUZIDA EM RATOS WISTAR

de autoria de:

MACHADO I FS (1)*, GARCIA CAR (1), ROMFIRO TH (1), MACHADO HR (1), IARDINI FO (1), MATIAS .IRI (1), LOPCS LS (1).

foi apresentado neste evento.

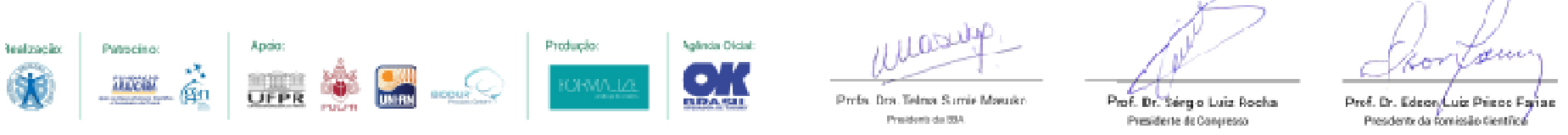

